\title{
Acetylated African Oil Bean Seed Pod For Crude Oil Spill Mop
}

Amalachukwu Ifeyinwa Obi ( $\square$ ai.obi@unizik.edu.ng )

Nnamdi Azikiwe University https://orcid.org/0000-0003-1002-9248

Vincent Ishmael Ajiwe

Nnamdi Azikiwe University

\section{Research Article}

Keywords: Oil bean seed pod, Acetylation, Oil spill mop

Posted Date: January 5th, 2022

DOI: https://doi.org/10.21203/rs.3.rs-1220132/v1

License: (c) (i) This work is licensed under a Creative Commons Attribution 4.0 International License. Read Full License 
*Correspondence: ai.obi@unizik.edu.ng

Department of Pure and Industrial Chemistry, Nnamdi Azikiwe University, Awka, Anambra State, Nigeria.

Oil spill remediation has continued to be a challenge in the world today. Thus efforts are still been made to develop more efficient oil spill mop up techniques. Natural adsorption with agricultural wastes, which otherwise constitute environmental pollution, has become an attractive technique for oil spill mop. Acetylation using acetic anhydride with iodine catalyst was carried out to improve the hydrophobicity of African oil bean seed pod (AOBSP), which is a lignocellulosic material and as such is naturally hydrophilic. Characterization of the raw and acetylated AOBSP were done using SEM, BET and FTIR analyses. Batch crude oil sorption tests were performed using both the raw and acetylated AOBSP. Isotherm, kinetic and thermodynamic studies were also carried out. FTIR analysis showed evidence of successful acetylation of AOBSP and adsorption of crude oil onto the raw and acetylated AOBSP. SEM and BET analyses showed improvement of the surface properties of AOBSP by the acetylation process. The BET surface area increased from $226.4 \mathrm{~m}^{2} / \mathrm{g}$ for the raw AOBSP to $310.0 \mathrm{~m}^{2} / \mathrm{g}$ for the acetylated AOBSP. Oil sorption was found to be by monolayer coverage, with monolayer sorption capacity of $5000 \mathrm{mg} / \mathrm{g}$ and $12500 \mathrm{mg} / \mathrm{g}$ for raw and acetylated AOBSP, respectively. study show that both raw and acetylated AOBSP are efficient oil sorbents with potentials for further 24 improvement for oil spill mop. 
Keywords: Oil bean seed pod, Acetylation, Oil spill mop

\section{INTRODUCTION}

27 Environmental pollution due to crude oil spillage occurs during the various stages of its extraction, transportation, refining, storage, and use. Up to 100 million gallons of crude oil have been estimated to spill into marine environments each year (Barros et al. 2014). This causes adverse effects on aquatic life, human life, local economies, tourism, as well as leisure activities (Wali et al. 2019). Thus, so many efforts are being made towards the development of a very suitable means of oil spill remediation. Many mechanical, biological, chemical and adsorption technologies are been used for removal of oil spills in aqueous environments. However, natural adsorption method using low cost agricultural materials and wastes is a preferred method because of its simplicity, low cost, effectiveness as well as availability, renewability and biodegradability of the sorbents (Xu et al. 2018). These wastes themselves, as well as their disposal usually constitute environmental concerns ( $\mathrm{Li}$ et al. 2021). Thus, their conversion into valuable products will aid in providing solution to environmental pollution. The major snag with the use of agricultural materials and wastes in oil spill mop is the hydrophilic nature of the materials (Omer et al. 2020), which is as a result of their high hydroxyl content (Anuzyte and Vaisis, 2018). This can, however, be addressed by modification processes which confer hydrophobic properties to the materials (Thompson et al. 2015). Acetylation is one of the most commonly used modification methods, and it changes the hydrophilic nature of lignocellulosic materials to hydrophobic by replacing some of their hydroxyl (-OH) groups with acetyl groups $\left(-\mathrm{COCH}_{3}\right)$, which are hydrophobic (Onwuka et al. 2019). Acetylation of various agricultural materials such as corn silk (Asadpour et al., 2015), jute fibre (Teli and Valia 2016), corn cob (Nwadiogbu et al. 2016), cocoa pods and oil palm fruit empty bunch (Onwuka et al. 2018) have been carried out in order to improve their oil sorption capacity.

47 African oil bean seed pod is a readily available, biodegradable waste obtained from the African oil 48 bean tree (Pentaclethra macrophylla). It usually falls off from the tree after splitting open to expel the 
seeds which are highly nutritious and usually consumed as food condiment or snack after fermentation

or roasting (Nwosu et al. 2017). The empty dry pods are not useful and usually constitute environmental

51 pollution. Studies have been carried out on its use for production of activated carbon (Aningo et al.

52 2017) and adsorption of heavy metals (Okwunodulu et al. 2015). However, its acetylation for

53 improvement of crude oil sorption potential has not yet been studied.

\section{METHODS}

55 The crude oil used in this work was collected from Port Harcourt Refinery Rivers State, Nigeria. African oil bean seed pods (AOBSP) were collected from Awka environment in Anambra State,

57 Nigeria. They were thoroughly washed with clean water to remove dust and extraneous materials. Then they were dried under sunlight for 12 hours, and then transferred to an oven at $65^{\circ} \mathrm{C}$ to dry completely.

59 The dried samples were ground using manual grinding machine and sieved. The particles that passed 60 through size 25 British standard sieves (BSS Sieves) were collected and used for further analyses.

61 Acetic anhydride, iodine and all other chemicals used in this work were obtained from British Drug 62 Houses, Ltd.

\section{Crude oil characterization}

64 The density of the crude oil was determined using the density bottle method as reported by Oloro 65 (2018). The ${ }^{\circ}$ API gravity was obtained using the formula for API (American Petroleum Institute) 66 gravity as expressed by Al-Dahhan and Mahmood (2019). The viscosity of the crude oil was obtained 67 using an NDJ-85 Digital rotary viscometer at $27^{\circ} \mathrm{C}$.

\section{Soxhlet extraction}

69 In order to reduce the influence of fiber extracts on acetylation, soxhlet extraction was carried out on 70 the AOBSP. For this, $10 \mathrm{~g}$ of the sieved materials were extracted with a mixture of $\mathrm{n}$-hexane and acetone $71(4: 1, \mathrm{v} / \mathrm{v})$ for 5 hours. The extracted samples were dried in a laboratory oven for 16 hours. 


\section{Acetylation reaction}

74 Acetylation of AOBSP was carried out under mild conditions using the method reported by Nwabueze 75 et al. (2005) which involved acetylation without solvent. A weighed portion (3g) of the AOBSP was 76 reacted with acetic anhydride $(60 \mathrm{~mL})$ in the presence of $1 \%$ iodine catalyst at $30^{\circ} \mathrm{C}$ for 1 hour. The 77 acetylated samples were then dried in an oven at $60^{\circ} \mathrm{C}$ for 16 hours, after which they were cooled and 78 stored for further analysis.

\section{Sorbent characterization}

80 Fourier-Transform Infrared (FTIR) spectra was collected using a Nicolet iS5 spectrometer in the 81 spectral range of $4000-400 \mathrm{~cm}^{-1}$ in attenuated total reflection (ATR) mode. This was used to identify 82 the functional groups present in the raw and acetylated AOBSP. The surface morphologies of the raw 83 and acetylated AOBSP were observed using Phenom ProX Scanning Electron Microscope by 84 PhenomWorld Eindhoven, the Netherlands. The surface area, pore volume and size were determined 85 using BET analyzer (Quantachrome NOVA 4200e).

\section{Crude oil adsorption}

87 Crude oil for the sorption test was left in a beaker for 24 hours in open air to release volatile 88 hydrocarbon contents, and thus simulate real oil spill situation. Batch sorption tests were carried out 89 using the method described by Nwadiogbu et al. (2016) by contacting $0.2 \mathrm{~g}$ each of the raw and acetylated AOBSP with $10 \mathrm{~g}$ of the weathered crude oil displaced in $100 \mathrm{~mL}$ of water at $26^{\circ} \mathrm{C}$. After

$9115 \mathrm{mins}$ the sorbents were removed using sieving nets and dried at $60^{\circ} \mathrm{C}$ for 30 minutes, after which they

92 were re-weighed. Oil sorption capacity (g/g) was calculated according to the standard method (ASTM 93 F726-99) as shown in Equation 1.

$$
\text { Oil sorption capacity }=\frac{\mathrm{W}_{1}-\mathrm{W}_{0}}{\mathrm{~W}_{0}}
$$


where $\mathrm{W}_{0}$ and $\mathrm{W}_{1}$ are the weight of adsorbent before and after oil adsorption, respectively, and the quantity $\mathrm{W}_{1}-\mathrm{W}_{0}$ is the amount of crude oil adsorbed in grams. The amount of crude oil adsorbed per unit weight of adsorbent, $\mathrm{q}_{\mathrm{e}}(\mathrm{mg} / \mathrm{g})$, was calculated using Equation 2.

$$
\mathrm{qe}_{\mathrm{e}}=\frac{\left(\mathrm{C}_{\mathrm{o}}-\mathrm{C}_{\mathrm{e}}\right) \mathrm{V}}{\mathrm{m}}
$$

where $\mathrm{C}_{\mathrm{o}}$ is the initial crude oil concentration $(\mathrm{mg} / \mathrm{L}), \mathrm{C}_{\mathrm{e}}$ is the equilibrium crude oil concentration $(\mathrm{mg} / \mathrm{L}), \mathrm{m}$ is the mass of the adsorbent $(\mathrm{g})$ and $\mathrm{V}$ is the volume of the solution $(\mathrm{L})$.

\section{Kinetic study}

Three well known kinetic models were employed to study the kinetics of the oil adsorption. These are the pseudo first order, pseudo second order and intraparticle diffusion models.

\section{The pseudo first order kinetic model}

The linearized pseudo first order equation is as shown in Equation 3 (Ho and McKay, 2000).

$$
\ln \left(\mathrm{q}_{\mathrm{e}}-\mathrm{q}_{\mathrm{t}}\right)=\ln \mathrm{q}_{\mathrm{e}}-\mathrm{k}_{1} \mathrm{t}
$$

where $\mathrm{q}_{\mathrm{e}}$ is the amount of adsorbate adsorbed at equilibrium $(\mathrm{mg} / \mathrm{g}), \mathrm{q}_{\mathrm{t}}$ is the amount of adsorbate adsorbed in $\mathrm{mg} / \mathrm{g}$ at time $\mathrm{t}(\mathrm{min})$, and $\mathrm{k}_{1}$ is the pseudo first order reaction rate constant $\left(\mathrm{min}^{-1}\right)$. A plot of $\ln \left(\mathrm{q}_{\mathrm{e}}-\mathrm{q}_{\mathrm{t}}\right)$ versus $\mathrm{t}$ gives a straight line graph yielding $\mathrm{k}_{1}$ and $\mathrm{q}_{\mathrm{e}}$ from its slope and intercept, respectively.

\section{The pseudo second order kinetic model}

The linearized pseudo second order equation is as expressed in Equation 4 (Ofomaja and Ho, 2007).

$$
\frac{\mathrm{t}}{\mathrm{q}_{\mathrm{t}}}=\frac{1}{\mathrm{k}_{2} \cdot \mathrm{q}_{\mathrm{e}}^{2}}+\frac{\mathrm{t}}{\mathrm{q}_{\mathrm{e}}}
$$

where $\mathrm{q}_{\mathrm{e}}$ and $\mathrm{q}_{\mathrm{t}}$ are the sorption capacity $\left(\mathrm{mg} / \mathrm{g}\right.$ ) at equilibrium and at time $\mathrm{t}(\mathrm{min})$, respectively, and $\mathrm{k}_{2}$ is the pseudo-second order reaction rate constant (g/mg.min). A plot of $\mathrm{t} / \mathrm{q}_{\mathrm{t}}$ versus $\mathrm{t}$ should give a linear relationship, from which $\mathrm{q}_{\mathrm{e}}$ and $\mathrm{k}_{2}$ can be determined from the slope and intercept of the plot, respectively. 
120 The intraparticle diffusion model is expressed in Equation 5 (Idris et al. 2012).

$$
\mathrm{q}_{\mathrm{t}}=\mathrm{K}_{\mathrm{id}} \mathrm{t}^{0.5}+\mathrm{C}
$$

122 where $\mathrm{K}_{\mathrm{id}}$ is the rate constant of intraparticle diffusion $\left(\mathrm{mg} /\left(\mathrm{g} \cdot \mathrm{min}^{0.5}\right)\right), \mathrm{t}^{0.5}$ is the square root of the time, 123 and $\mathrm{C}$ is the intercept.

\section{Isotherm study}

125 Two popular isotherms were used to study the equilibrium of the oil adsorption process. They are 126 Langmuir isotherm and Freundlich isotherm.

\section{$127 \quad$ Langmuir isotherm}

128 The linearized Langmuir isotherm is expressed in Equation 6 (Santos et al. 2015).

$$
\frac{\mathrm{C}_{\mathrm{e}}}{\mathrm{q}_{\mathrm{e}}}=\frac{1}{\mathrm{~K}_{\mathrm{L}} \cdot \mathrm{q}_{\mathrm{m}}}+\frac{\mathrm{C}_{\mathrm{e}}}{\mathrm{q}_{\mathrm{m}}}
$$

where $\mathrm{q}_{\mathrm{m}}$ is the maximum monolayer adsorption capacity $(\mathrm{mg} / \mathrm{g})$ and $\mathrm{K}_{\mathrm{L}}(\mathrm{L} / \mathrm{mg})$ is the Langmuir or equilibrium constant of adsorption which is a measure of affinity of the adsorbate for the adsorbent and

132 is related to the energy of sorption. A plot of $\frac{C_{e}}{q_{e}}$ against $C_{e}$ yields a straight line graph whose slope and 133 intercept can be used to determine $\mathrm{q}_{\mathrm{m}}$ and $\mathrm{k}_{\mathrm{L}}$, respectively. A dimensionless constant called the 134 separation factor or equation parameter, $\mathrm{R}_{\mathrm{L}}$, which is expressed in Equation 7 (Gupta et al. 2001) is 135 used to predict the affinity between an adsorbent and adsorbate.

$$
\mathrm{R}_{\mathrm{L}}=\frac{1}{1+\mathrm{k}_{\mathrm{L}} \cdot \mathrm{C}_{\mathrm{o}}}
$$

137 where, $\mathrm{C}_{\mathrm{o}}$ is the initial adsorbate concentration. The value of $\mathrm{R}_{\mathrm{L}}$ indicates the adsorption nature to be 138 unfavorable if $R_{L}>1$, linear if $R_{L}=1$, favorable if $0<R_{L}<1$ and irreversible if $R_{L}=0$.

\section{$139 \quad$ Freundlich isotherm}

140 The linearized Freundlich equation is expressed in Equation 8 (Shah et al. 2021). 
142 where, $\mathrm{K}_{\mathrm{F}}\left[(\mathrm{mg} / \mathrm{g}) /(\mathrm{mg} / \mathrm{L})^{1 / \mathrm{n}}\right]$ is the Freundlich constant, which indicates the relative adsorption

143 capacity of the adsorbent, and $\mathrm{n}$ is a measure of the adsorption intensity showing the heterogeneity of

144 the adsorbent site and the energy of distribution. The values of $K_{F}$ and $n$ are determined from the 145 intercept and slope, respectively, of a linear plot of $\ln \mathrm{q}_{\mathrm{e}}$ as a function of $\ln \mathrm{C}_{\mathrm{e}}$. Values of $\mathrm{n}$ between 1 146 and 10 indicate favourable adsorption (Karthikeyan et al., 2003).

147 Thermodynamic studies

148 The standard Gibbs free energy changes for the adsorption processes was determined using van't Hoff 149 equation as shown in Equation 9 (Li et al. 2009).

150

$$
\Delta \mathrm{G}^{\mathrm{o}}=-\mathrm{RT} \ln \mathrm{K}_{\mathrm{d}}
$$

151 where $\Delta \mathrm{G}^{\mathrm{o}}$ is the free energy change $(\mathrm{kJ} / \mathrm{mol}), \mathrm{R}$ is the universal constant $(8.314 \mathrm{~J} / \mathrm{mol} . \mathrm{K}), \mathrm{T}$ is the 152 absolute temperature $(\mathrm{K})$, and $\mathrm{K}_{\mathrm{d}}$ is distribution coefficient for the adsorption $\left(\mathrm{cm}^{3} / \mathrm{g}\right) . \mathrm{K}_{d} \mathrm{was}$ 153 calculated using Equation 10.

$$
\mathrm{K}_{\mathrm{d}}=\frac{\mathrm{C}_{\mathrm{s}}}{\mathrm{C}_{\mathrm{e}}}
$$

155 where $\mathrm{C}_{\mathrm{s}}$ is the amount of adsorbate adsorbed on the sorbent at equilibrium.

156 The changes in enthalpy, $\Delta \mathrm{H}^{0}(\mathrm{~kJ} / \mathrm{mol})$, and entropy, $\Delta \mathrm{S}^{\circ}(\mathrm{kJ} / \mathrm{mol} . \mathrm{K})$ were calculated using Equation 15711 (Babarinde et al. 2016).

$$
\Delta \mathrm{G}^{\mathrm{o}}=\Delta \mathrm{H}^{\mathrm{o}}-\mathrm{T} \Delta \mathrm{S}^{\mathrm{o}}
$$

159 A plot of $\Delta \mathrm{G}^{\circ}$ versus $\mathrm{T}$ gives a straight line graph from whose slope and intercept $\Delta \mathrm{S}^{\mathrm{o}}$ and $\Delta \mathrm{H}^{\mathrm{o}}$ are 160 obtained, respectively.

\section{RESULTS AND DISCUSSION}

162 The characterizing properties of the crude oil are shown in Table 1. 
Table 1: Crude oil characterization

\begin{tabular}{ll}
\hline Parameter & Value \\
\hline Density $\left(\mathrm{kg} / \mathrm{m}^{3}\right)$ & 876 \\
${ }^{\circ}$ API gravity & 25.897 \\
Viscosity (mPa.s) & 3.958 \\
\hline
\end{tabular}

166 The crude oil is less dense than water and so floats on water. It belongs to the class of medium crudes 167 since its density is within the range of $870-920 \mathrm{~kg} / \mathrm{m}^{3}$ (Awadh and Al-Mimar, 2015) and the ${ }^{\circ} \mathrm{API}$ 168 gravity is in the range of $22.3-31.1^{\circ}$ (Yasin et al. 2013). This implies that the crude oil has a blend of 169 light and heavy oils (Madu and Ugwu, 2017).

170 Surface Morphology Identification

171 The SEM images of the raw and acetylated AOBSP are shown in Figures 1 and 2, respectively. 172

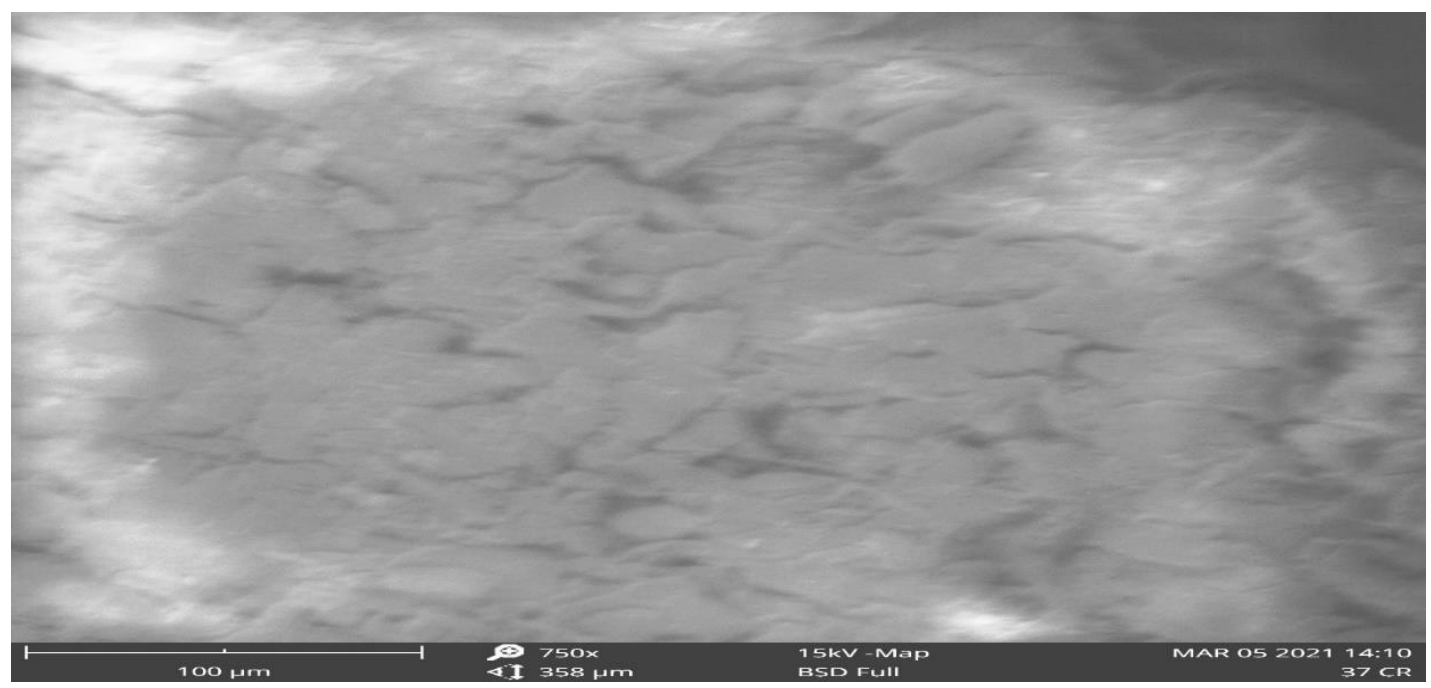

174 Figure 1: SEM micrograph of raw AOBSP 


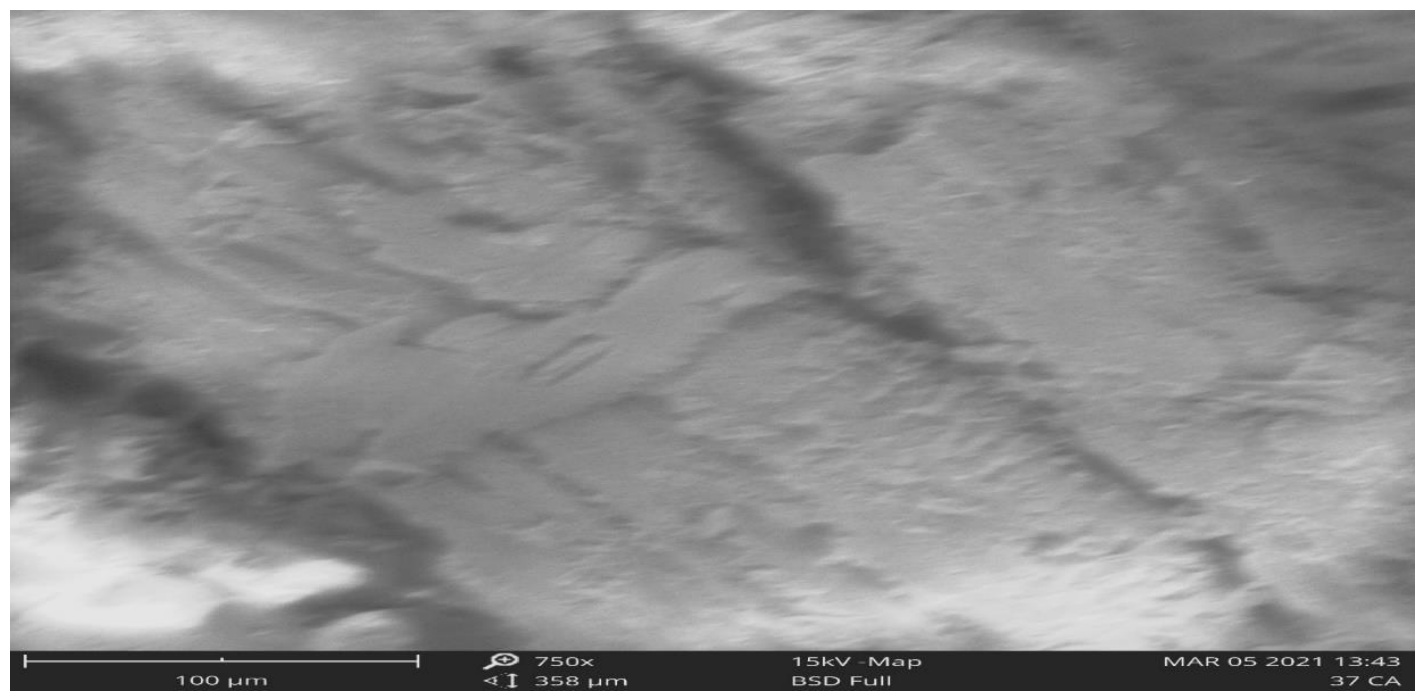

\section{Figure 2: SEM micrograph of acetylated AOBSP}

Acetylation increased the roughness and folds of the raw AOBSP surface, with formation of hollow structures. Similar observation was made by Asadpour et al. (2015) for the acetylation of corn silk. This change in morphology is due to the removal of weak constituents of hemicelluloses and lignin from the AOBSP structure by the acetylating agent (Mahmoud, 2020). This is desirable since it provides more spaces for the retention of oil in the sorbent, thus improving oil sorption and storage (Yusof et al. 2015).

\section{Surface Area Measurements}

The results of surface area, pore volume and pore size of the raw AOBSP are shown in Appendix 1A - $1 \mathrm{~J}$ while for acetylated AOBSP they are shown in Appendix 2A - 2J. The results are summarized in Table 2. According to the International Union of Pure and Applied Chemistry, pore sizes are classified into three groups, which are micropores (diameter less than $20 \AA$ or $2 \mathrm{~nm}$ ), mesopores (diameter between $20 \AA$ or $2 \mathrm{~nm}$ and $500 \AA$ or $50 \mathrm{~nm}$ ), and macropores (diameter greater than $500 \AA$ or $50 \mathrm{~nm}$ ) (Asadpour et al. 2014). The pore size/diameter of the raw and acetylated AOBSP were in the same range and belonged to the mesopore group. Acetylation was found to substantially increase the surface area and pore volume of AOBSP. These increments are likely due to the formation of hollow structures 
192 and increased roughness and folds of the raw AOBSP surface, as observed in SEM analysis. This is 193 favorable since high active surface area results in high oil adsorption capacity (Angelova et al. 2011).

\subsection{Fourier Transform Infra-red spectroscopy (FTIR)}

195 The FTIR spectra for raw and acetylated AOBSP, before and after crude oil sorption, are shown in 196 Figures 3 - 6, respectively. The assignment of functional groups are shown in Table 3.

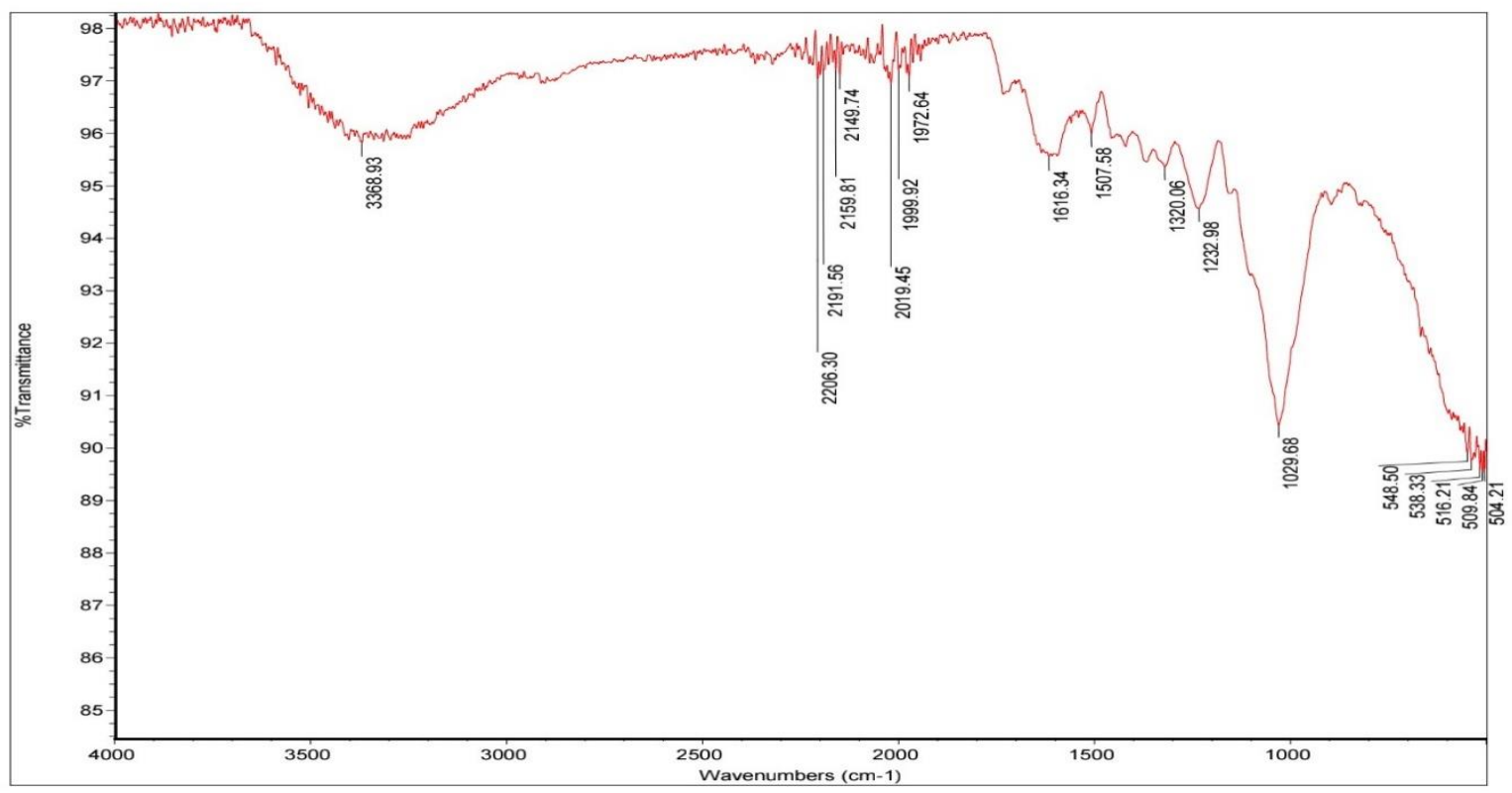

198 Figure 3: FTIR spectrum of raw African oil bean seed pod (RAOBSP)

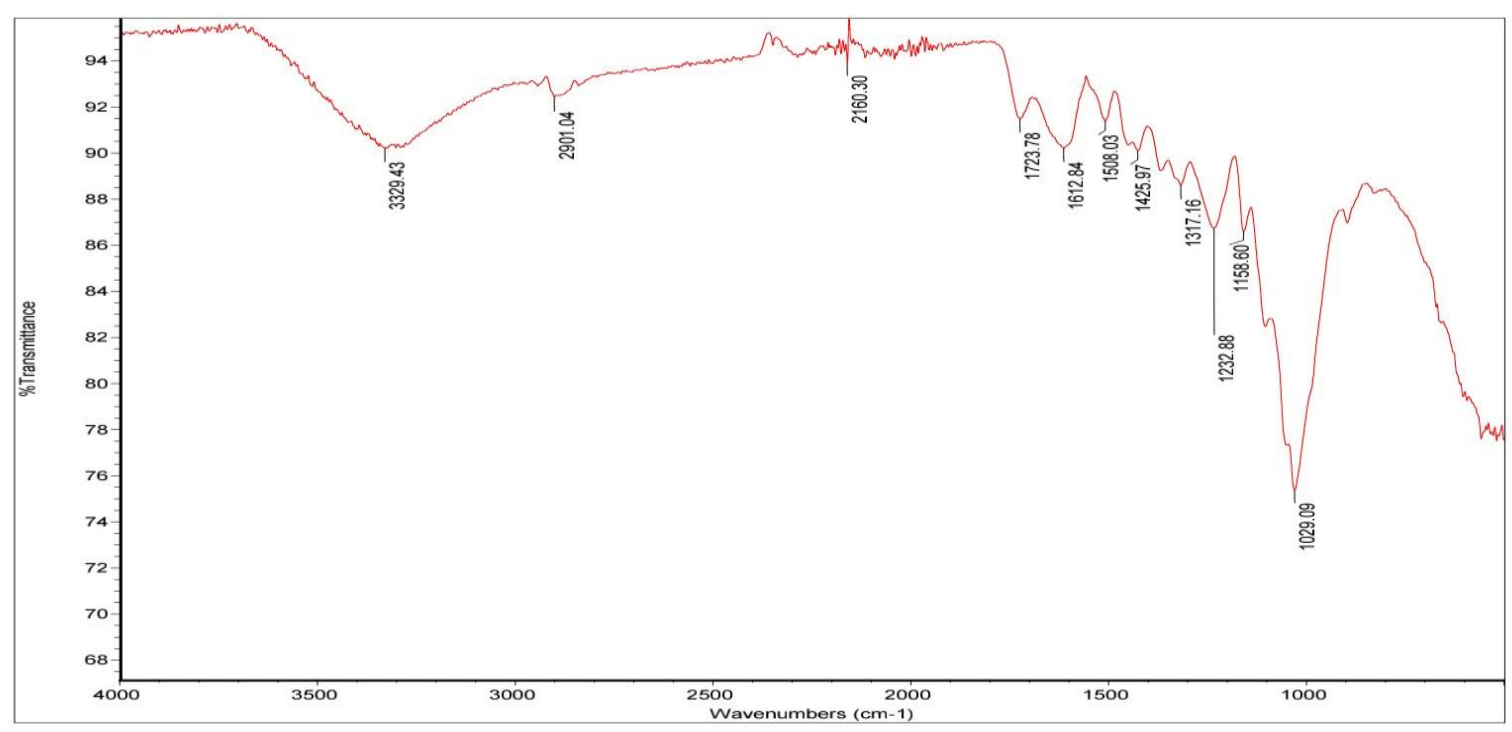




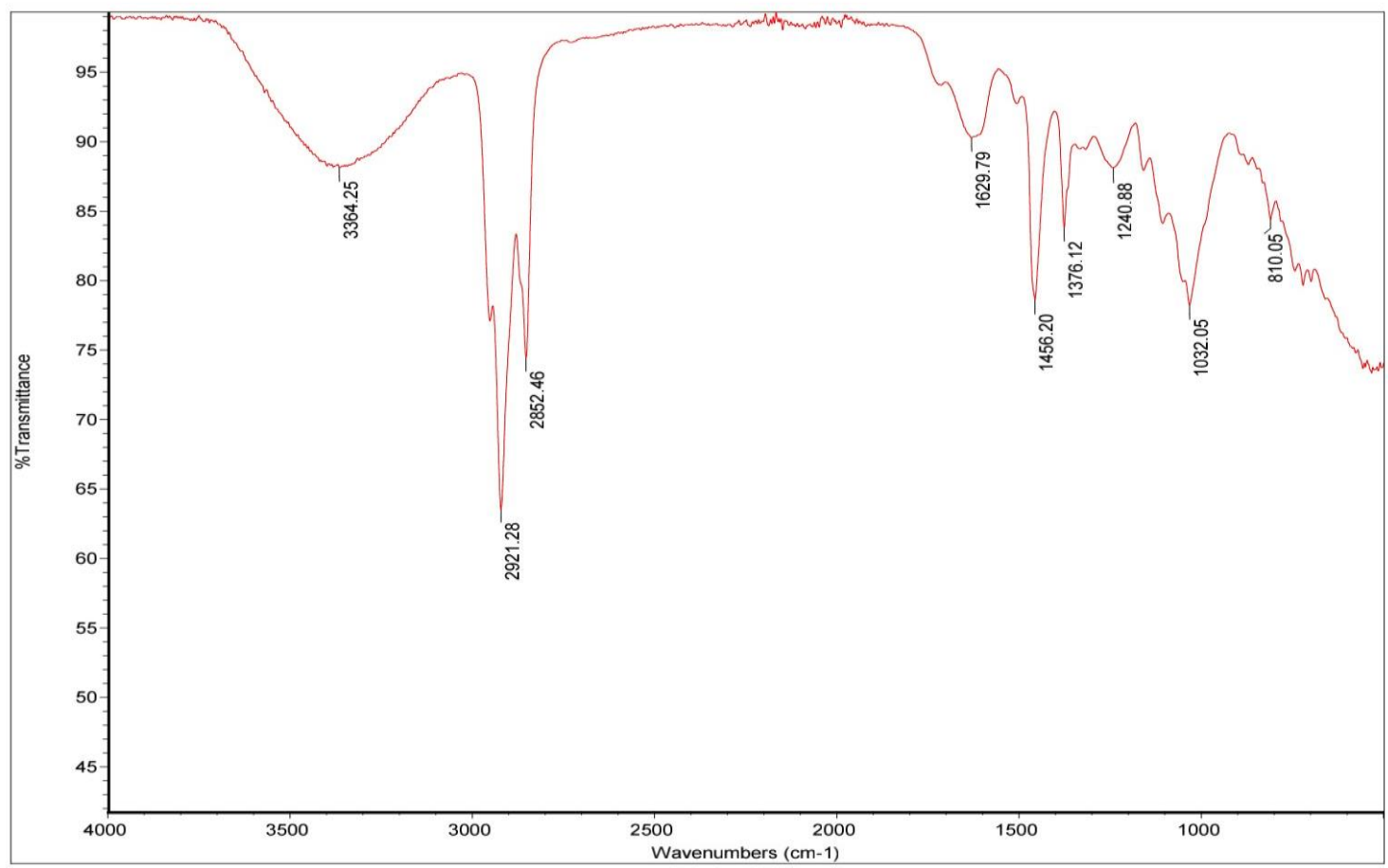

201

Figure 5: FTIR spectrum of raw African oil bean seed pod after sorption (RAOBSP-S)

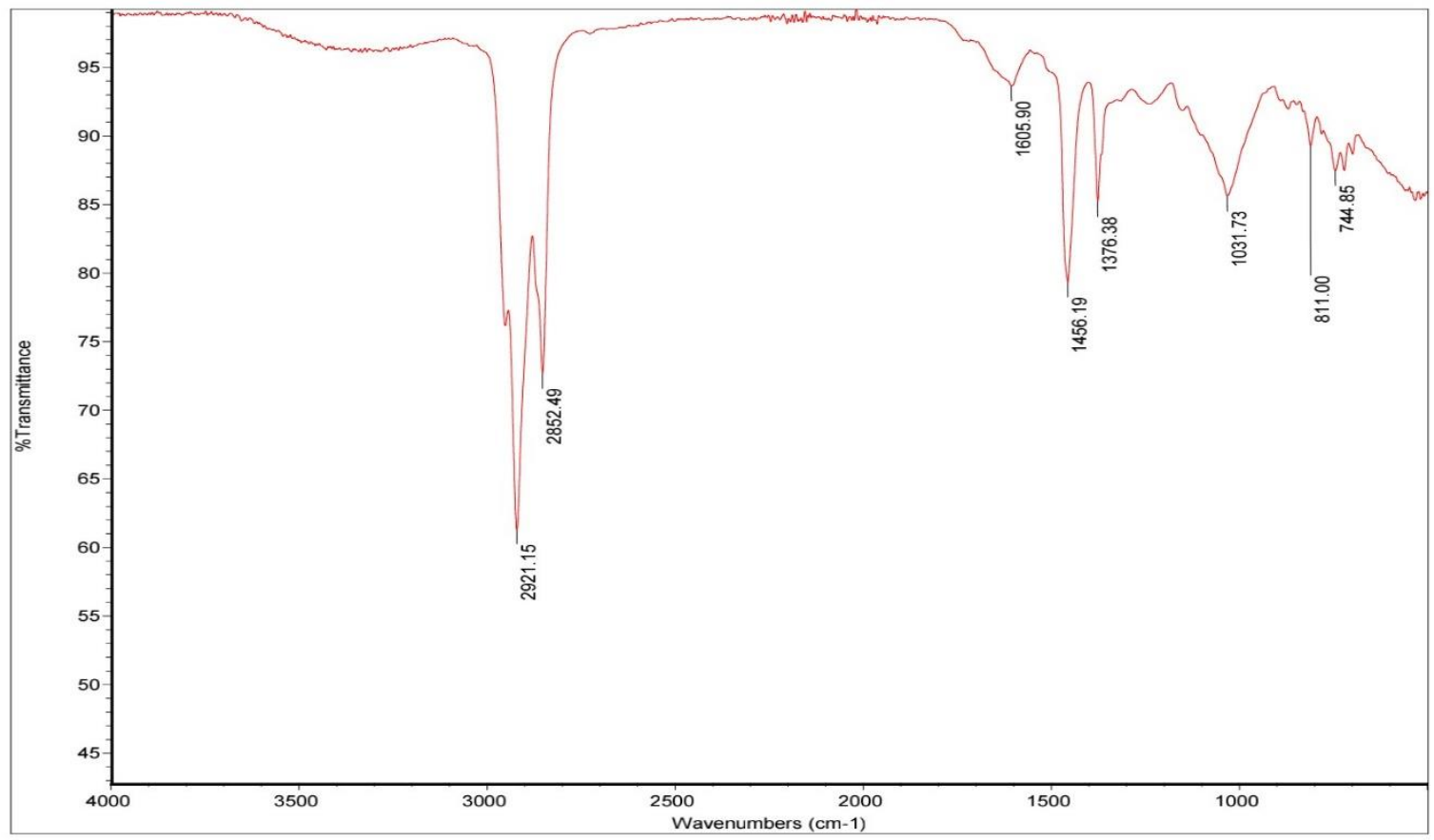


Table 3: FTIR bands of AOBSP and the corresponding functional groups

\begin{tabular}{|c|c|c|c|c|}
\hline $\begin{array}{c}\text { RAOBSP } \\
\left(\mathrm{cm}^{-1}\right)\end{array}$ & $\begin{array}{c}\text { AAOBSP } \\
\left(\mathbf{c m}^{-1}\right)\end{array}$ & $\begin{array}{c}\text { RAOBSP-S } \\
\qquad\left(\mathbf{c m}^{-1}\right)\end{array}$ & $\begin{array}{c}\text { AAOBSP-S } \\
\left(\mathbf{c m}^{-1}\right)\end{array}$ & Assignment \\
\hline 3368.93 & 3329.43 & 3364.25 & - & $\mathrm{O}-\mathrm{H}$ stretching in cellulose and hemicellulose \\
\hline- & 2901.04 & 2921.28 & 2921.15 & $\mathrm{C}-\mathrm{H}$ stretching of methyl and methylene groups \\
\hline 2191.56 & 2160.30 & 2852.46 & 2852.49 & Cyanide ion stretching \\
\hline \multirow[t]{2}{*}{1616.34} & 1723.78 & 1629.79 & 1605.90 & $\mathrm{C}=\mathrm{O}$ stretching vibration \\
\hline & 1612.84 & & & \\
\hline 1507.58 & 1508.03 & - & - & $\mathrm{C}=\mathrm{C}$ stretching of aromatic ring \\
\hline \multirow[t]{2}{*}{1320.06} & 1425.97 & 1456.20 & 1456.19 & $\mathrm{C}-\mathrm{H}$ bending \\
\hline & 1317.16 & 1376.12 & 1376.38 & \\
\hline 1232.98 & 1232.88 & 1240.88 & 1032.71 & $\mathrm{C}-\mathrm{O}$ stretching vibration \\
\hline \multirow[t]{2}{*}{1029.68} & 1158.60 & 1032.05 & & \\
\hline & 1029.09 & & & \\
\hline- & - & 810.05 & 810.75 & $\mathrm{C}-\mathrm{H}$ bending of $\beta$ glycosidic bond \\
\hline 548.50 & 534.12 & - & 744.63 & $\mathrm{C}-\mathrm{H}$ out of plane bending \\
\hline to & to & & & \\
\hline
\end{tabular}

$504.21 \quad 516.32$ crude oil sorption; and AAOBSP-S is acetylated AOBSP after crude oil sorption. 
A comparison of the spectra of RAOBSP and AAOBSP shows the following major differences:

210 creation of absorption peak at $2901.04 \mathrm{~cm}^{-1}$ (C-H stretching), enhancement of absorption peaks at $211 \quad 1612.84-1723.78 \mathrm{~cm}^{-1}(\mathrm{C}=\mathrm{O}$ stretching $)$ and at $1029 \mathrm{~cm}^{-1}(\mathrm{C}-\mathrm{O}$ stretching $)$. These show evidence of

212 acetylation of AOBSP (Onwuka et al. 2016). The lack of peaks at $1700 \mathrm{~cm}^{-1}$ (carboxylic group) and in 213 the region of $1760-1840 \mathrm{~cm}^{-1}$ in the spectra of the acetylated sample indicates that the product was free 214 of acetic acid byproduct and unreacted acetic anhydride (Bodîrlău and Teacă, 2009).

215 The spectra of the crude oil-treated sorbents show the appearance of intense sharp peaks at $2921 \mathrm{~cm}^{-1}$, $2162852 \mathrm{~cm}^{-1}$ and $1376.12-1456.40 \mathrm{~cm}^{-1}$ which correspond to $\mathrm{CH}_{3}, \mathrm{CH}_{2}$ and $\mathrm{C}-\mathrm{H}$ bending of crude oil 217 showing that crude oil was adsorbed to the adsorbents (Kudaybergenov et al. 2013). These peaks are 218 found to be more intense in AAOBSP-S than RAOBSP-S showing that the acetylated sample adsorbed 219 more crude oil than the raw sample. The spectra of AAOBSP-S shows absence of peak at $3329.43-$ $2203368.93 \mathrm{~cm}^{-1}(\mathrm{O}-\mathrm{H}$ stretching $)$, as well as reduced peaks at $1029.09-1232.98 \mathrm{~cm}^{-1}(\mathrm{C}-\mathrm{O}$ stretching $)$ 221 and $1605.63-1629.79 \mathrm{~cm}^{-1}(\mathrm{C}=\mathrm{O}$ stretching $)$. This may indicate the involvement of these groups in the 222 adsorption of crude oil to the acetylated sample (Shittu et al. 2020). The obtained FTIR spectra are 223 consistent with those reported for crude oil adsorption by raw and acetylated corn silk (Asadpour et al. 224 2015) and Delonix regia pods (Onwuka et al. 2016).

\section{Adsorption Studies}

226 The effects of different parameters on the crude oil sorption capacity of both the raw and acetylated 227 AOBSP were studied and the results are as follows.

\section{Effect of contact time}

229 The effect of contact time on crude oil sorption capacity of the raw and acetylated AOBSP is shown in $230 \quad$ Figure 7. 


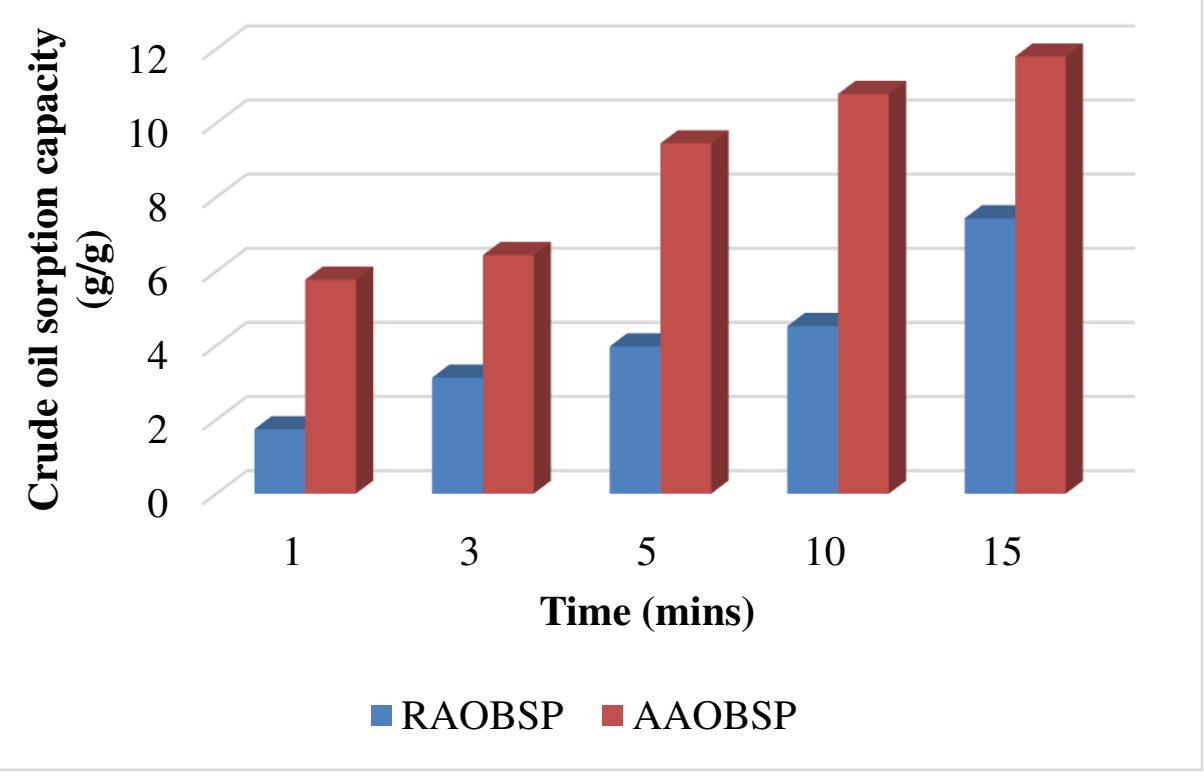

232

Figure 7: Effect of contact time on crude oil sorption capacity

233 The crude oil sorption capacity of the adsorbents was found to increase with increase in contact time 234 from 1 to 15 minutes. The sorption process was rapid at the initial stages of contact and thereafter it 235 became slower towards equilibrium. This may be due to the fact that at the onset of contact, the high 236 concentration gradient between the oil solution and the sorbent surface leads to high diffusion of oil 237 into the pores of the sorbent. But, as time passed, the adsorbed oil started to clog the sorbent's pores 238 and so oil could no longer diffuse to the active sites deep within the sorbent (Najaa-Syuhada et al. 239 2017). Similar trend was reported for crude oil adsorption on raw and acetylated Borassus aethopum 240 coir by Arinze-Nwosu et al. (2019).

241 Throughout the adsorption period, the acetylated AOBSP had higher sorption capacity than the raw 242 AOBSP. At 15minutes of contact time, the sorption capacities of the raw and acetylated AOBSP were $2437.430 \mathrm{~g} / \mathrm{g}$ and $11.795 \mathrm{~g} / \mathrm{g}$, respectively. The higher sorption capacity of the acetylated AOBSP is likely 244 due to its higher surface area and pore volume, as observed in surface area analysis, which provides 245 more spaces for oil adsorption. Increase in crude oil sorption capacity on acetylation was also reported 246 by Onwuka et al. (2018) who found the crude oil adsorption capacity of raw and acetylated cocoa pods 
247 to be 3.97 and $6.65 \mathrm{~g} / \mathrm{g}$, respectively, while raw and acetylated oil palm empty fruit bunch had values 248 of 3.04 and $6.48 \mathrm{~g} / \mathrm{g}$, respectively.

249 Effect of temperature

250 The effect of temperature on the crude oil sorption capacity of the raw and acetylated AOBSP is shown 251 in Figure 8.

252

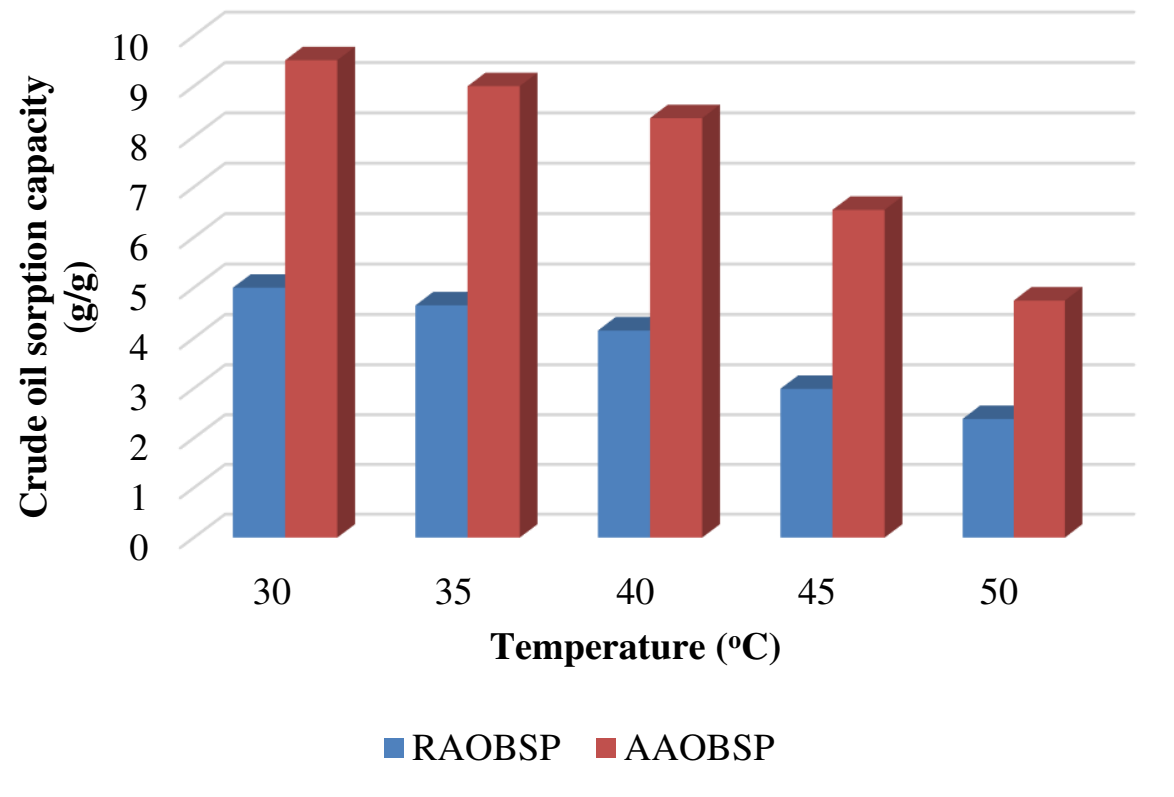

Figure 8: Effect of temperature on crude oil adsorption capacity

254 Crude oil sorption capacity decreased with increase in temperature from $30^{\circ} \mathrm{C}$ to $50^{\circ} \mathrm{C}$. This may be 255 due to the fact that increase in temperature accelerates the Brownian motion of the oil molecules, thus 256 a stronger force is needed to keep the molecules adsorbed to the sorbent surface (Simonivić et al. 2009). 257 The decrease in the crude oil sorption capacity with increasing temperature also shows that the 258 adsorption process was exothermic in nature. Similar behaviour was reported by El-Din et al. (2018) 259 for the use of banana peels to adsorb 1-day and 7-day weathered crude oil. An increase in temperature 260 from 20 to $45^{\circ} \mathrm{C}$ resulted in decrease of sorption capacity of the sorbent from $7.94 \mathrm{~g} / \mathrm{g}$ and $7.14 \mathrm{~g} / \mathrm{g}$ to $2614.52 \mathrm{~g} / \mathrm{g}$ and 3.25g/g for 1-day and 7-day weathered crude oil, respectively. 
263 The effect of adsorbent dose on the crude oil sorption capacity of the raw and acetylated AOBSP is

264 shown in Figure 9 while the effect of adsorbent dose on the amount of crude oil adsorbed is shown in 265 Figure 10.
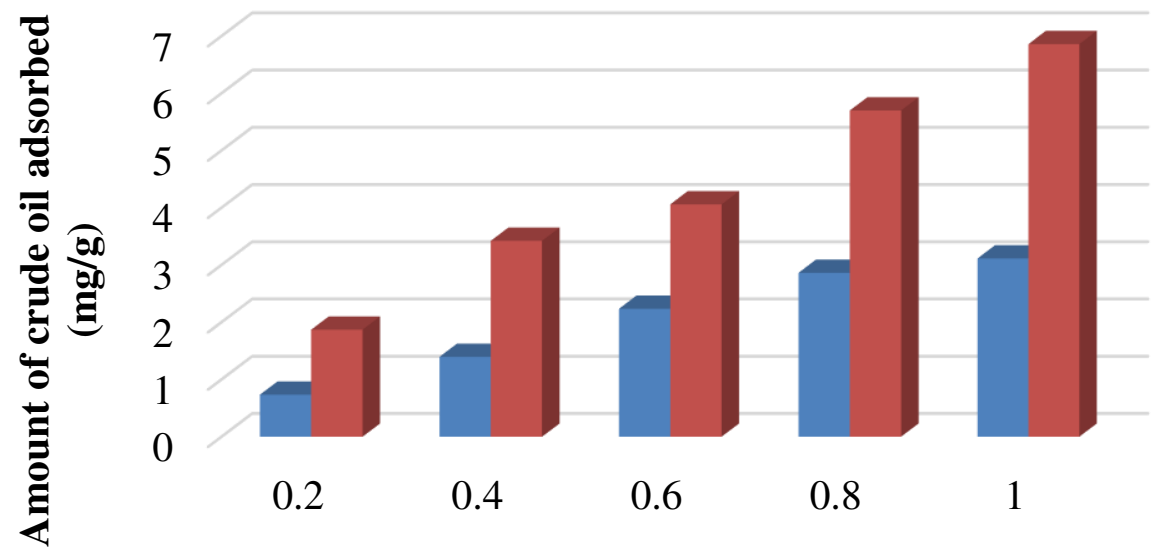

Adsorbent dose (g)

$\square$ RAOBSP $\square$ AAOBSP

Figure 9: Effect of adsorbent dose on amount of crude oil adsorbed
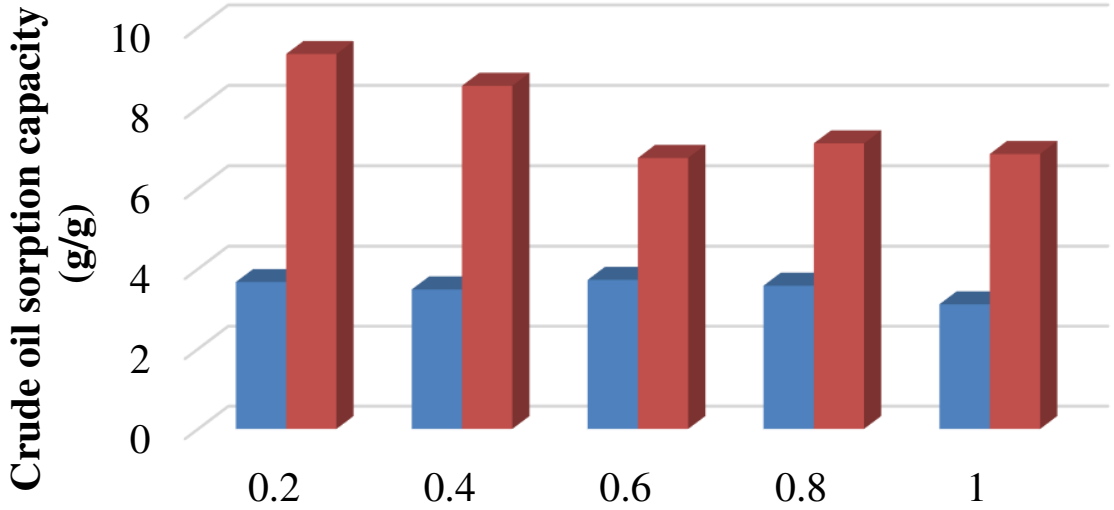

Adsorbent dose (g)

- RAOBSP AAOBSP

Figure 10: Effect of adsorbent dose on crude oil sorption capacity 
271 As sorbent dose increased from $0.2 \mathrm{~g}$ to $1 \mathrm{~g}$, amount of crude oil adsorbed on both the raw and acetylated

272 AOBSP increased from $0.734 \mathrm{mg} / \mathrm{g}$ to $3.113 \mathrm{mg} / \mathrm{g}$ and $1.869 \mathrm{mg} / \mathrm{g}$ to $6.860 \mathrm{mg} / \mathrm{g}$, respectively. This may

273 be due to the fact that increase in quantity of adsorbent resulted in the availability of more surface

274 area/active binding sites (Akinhanmi et al. 2020). However, as the sorbent dose increased, there was a

275 general decrease in the crude oil sorption capacity of both the raw and acetylated AOBSP. This decrease

276 may be due to the fact that as sorbent dose increases, sorption sites aggregate and overlap, thereby

277 reducing total accessible surface area. This results in reduction of the quantity of sorbate adsorbed by

278 a unit mass of sorbent, which leads to reduction of sorption capacity (Shweta and Jha 2016). Similar

279 behaviour was reported by Nwadiogbu et al. (2016) who found the crude oil sorption capacity of raw

280 and acetylated corn cob to decrease from $4000 \mathrm{mg} / \mathrm{g}$ to $1000 \mathrm{mg} / \mathrm{g}$ and $2300 \mathrm{mg} / \mathrm{g}$ to $500 \mathrm{mg} / \mathrm{g}$,

281 respectively on increasing the sorbent dosage from $0.5 \mathrm{~g}$ to $2 \mathrm{~g}$.

\section{Kinetic study}

283 The pseudo first order, pseudo second order and intraparticle diffusion data for crude oil adsorption on 284 raw and acetylated AOBSP are shown in Figures $11-13$.

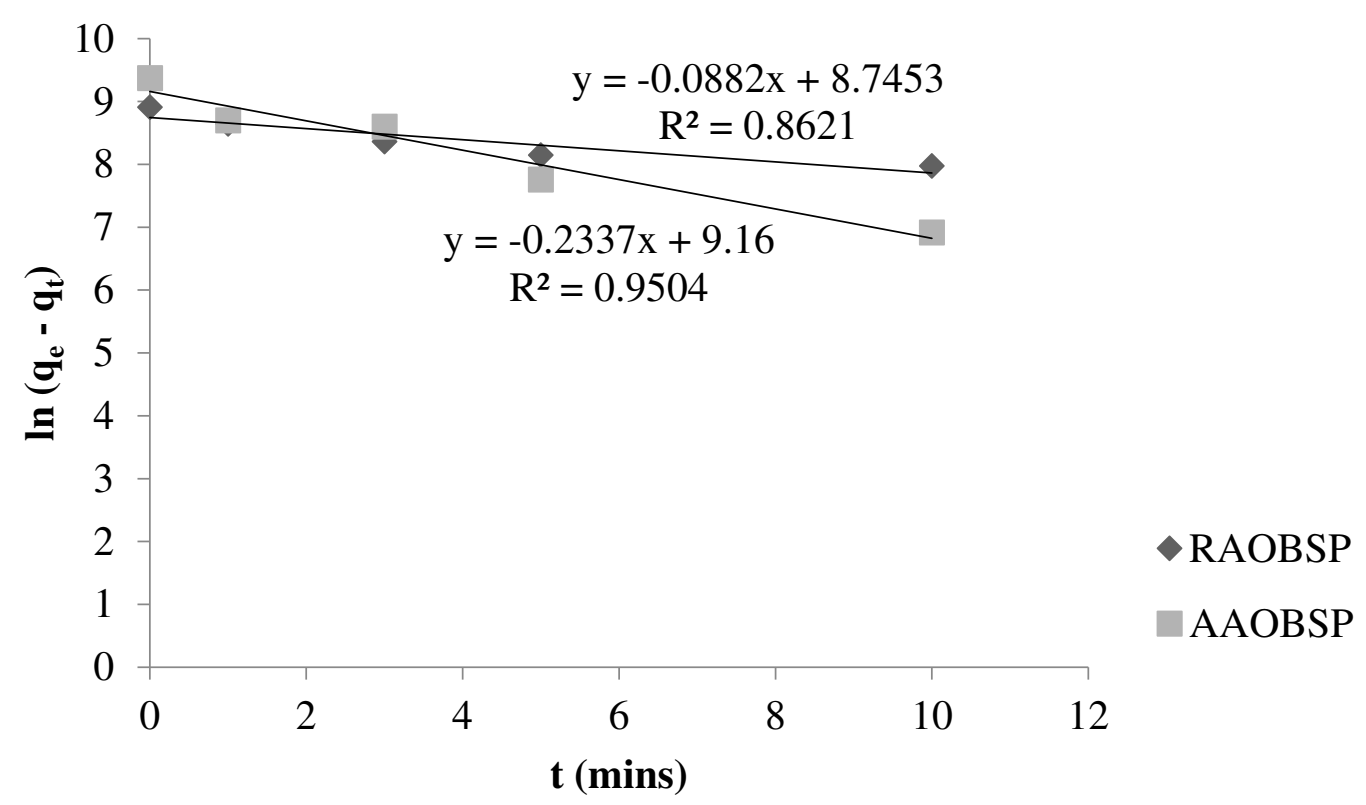




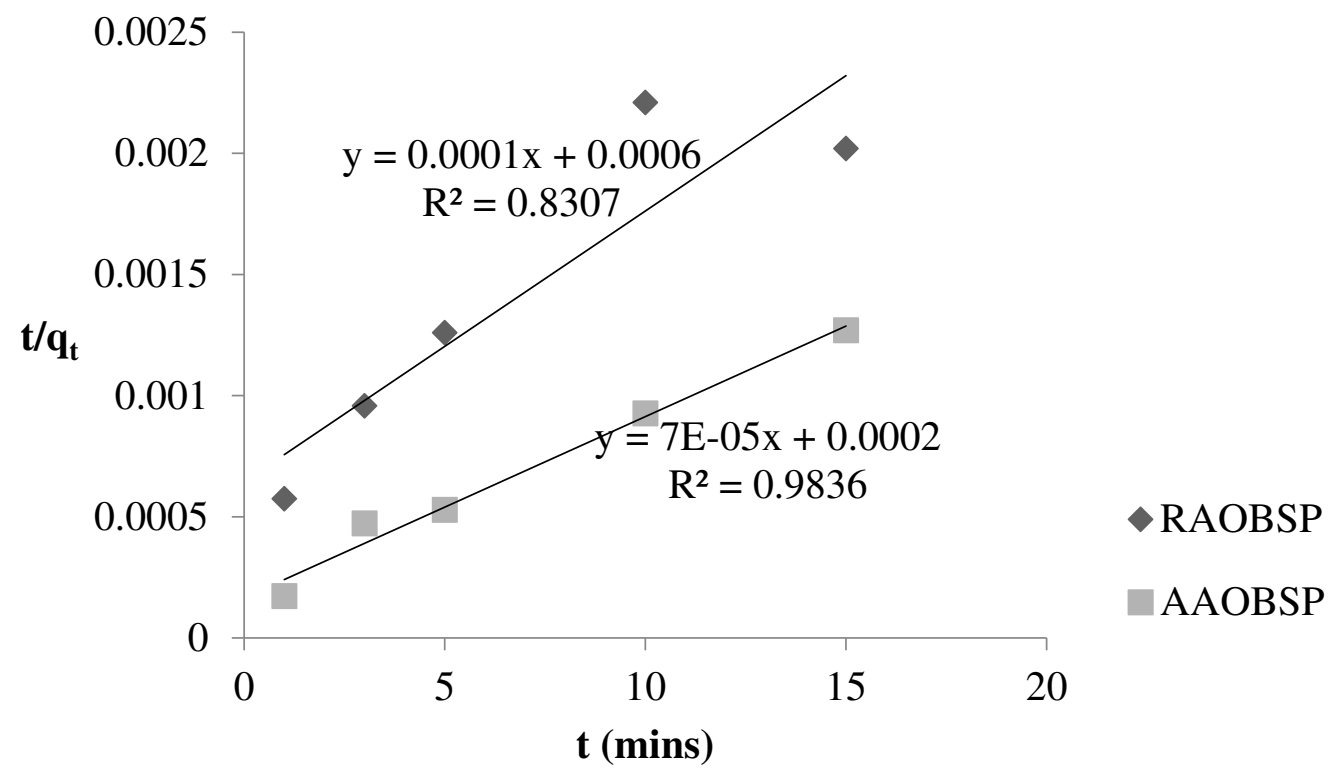

Figure 12: Pseudo second order kinetic plot

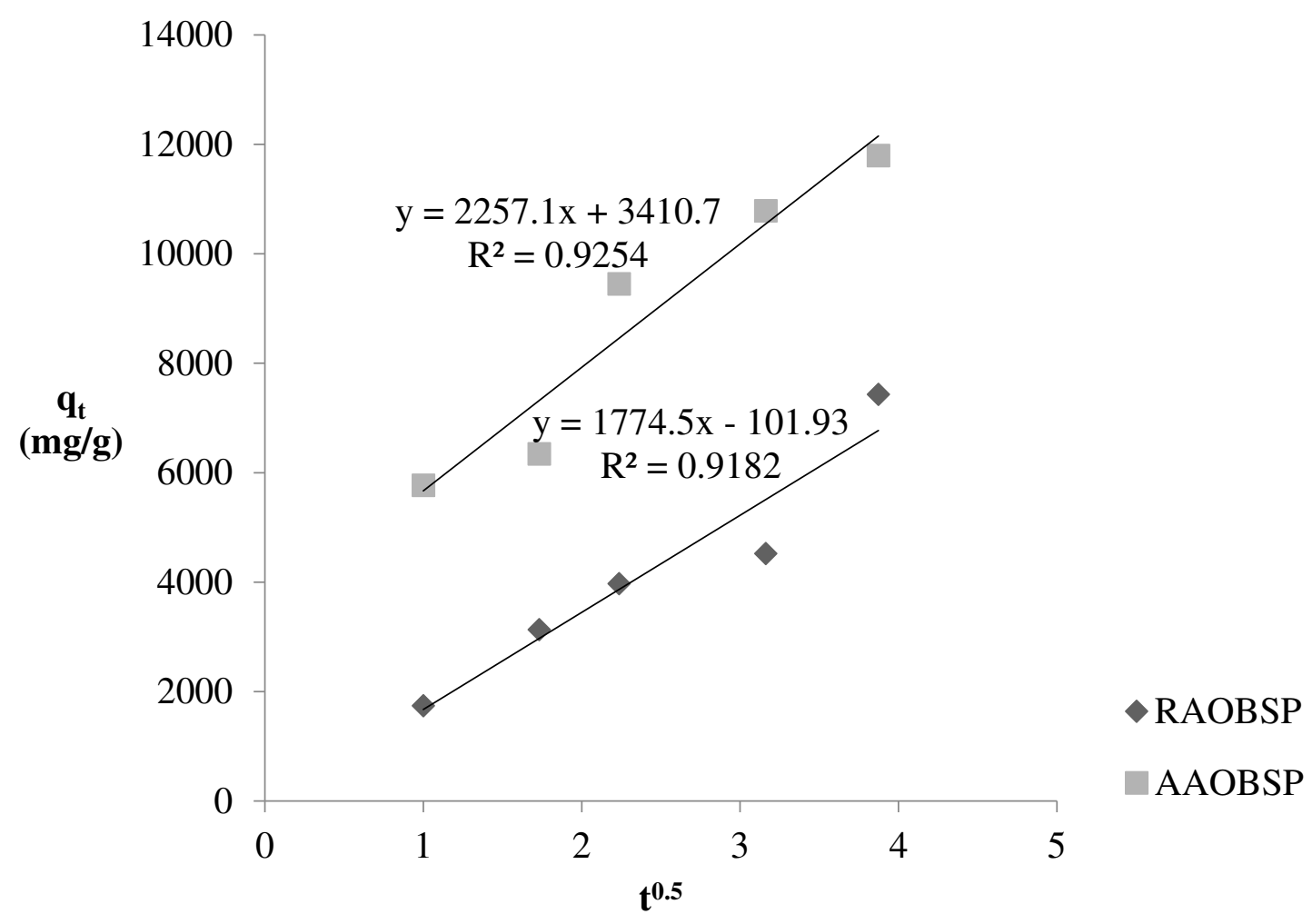

Figure 13: Intra particle diffusion kinetic plot

292 The kinetic parameters are shown in Table 4. 
Table 4: Kinetic parameters for oil adsorption on raw and acetylated AOBSP

\begin{tabular}{|c|c|c|}
\hline Parameter & RAOBSP & AAOBSP \\
\hline $\mathrm{q}_{\mathrm{e}}, \exp (\mathrm{mg} / \mathrm{g})$ & 7430 & 11795 \\
\hline \multicolumn{3}{|c|}{ Pseudo first order model } \\
\hline $\mathrm{R}^{2}$ & 0.8621 & 0.9504 \\
\hline $\mathrm{k}_{1}\left(\min ^{-1}\right)$ & 0.0882 & 0.2337 \\
\hline $\mathrm{q}_{\mathrm{e}}$, calc. $(\mathrm{mg} / \mathrm{g})$ & 6281 & 9509 \\
\hline \multicolumn{3}{|c|}{ Pseudo second order model } \\
\hline $\mathrm{R}^{2}$ & 0.8307 & 0.9836 \\
\hline $\mathrm{k}_{2}\left(\min ^{-1}\right)$ & $1.7 \times 10^{-5}$ & $2.5 \times 10^{-5}$ \\
\hline $\mathrm{q}_{\mathrm{e}}$, calc. $(\mathrm{mg} / \mathrm{g})$ & 10000 & 14286 \\
\hline \multicolumn{3}{|c|}{ Intraparticle diffusion model } \\
\hline $\mathrm{R}^{2}$ & 0.9182 & 0.9254 \\
\hline $\mathrm{K}_{\text {id }}\left(\mathrm{mg} /\left(\mathrm{g} \cdot \min ^{0.5}\right)\right)$ & 1774.5 & 2257.10 \\
\hline $\mathrm{C}$ & -101.93 & 3410.70 \\
\hline
\end{tabular}

294 All the kinetic plots were found to be linear with high $\mathrm{R}^{2}$ values $(0.8307-0.9836)$. The pseudo-first, 295 pseudo-second and intraparticle diffusion rate constants are higher for adsorption on acetylated AOBSP 296 than on raw AOBSP. This suggests that physisorption, chemisorption as well as intraparticle diffusion 297 of the crude oil was faster on acetylated AOBSP than on raw AOBSP, and this can be ascribed to the 298 hydrophobicity of the acetylated AOBSP (Onwuka et al. 2016). The intra particle diffusion model 299 graphs, though linear, did not pass through the origin. This shows that intra-particle diffusion took part 300 in controlling the rate of oil sorption on both RAOBSP and AAOBSP, but it was not the sole mechanism 301 (Thompson et al. 2015). The Kid value of AAOBSP was found to be higher than that of RAOBSP 

showing that acetylation improved the adsorptive potential of AOBSP since higher $\mathrm{K}_{\mathrm{id}}$ values indicate

303 increase in the rate of adsorption as well as better adsorption mechanism (Erhan et al. 2004).

304 For adsorption on both raw and acetylated AOBSP, the pseudo-second order rate constant is lower than 305 the pseudo-first order rate constant. This shows that chemisorption is the slowest step, and so is the 306 rate-controlling step in the sorption process. This is supported by the fact that for adsorption on 307 acetylated AOBSP, the pseudo-second-order $\mathrm{R}^{2}$ value (0.9836) is higher than the pseudo-first-order $\mathrm{R}^{2}$ 308 value (0.9504). For adsorption on raw AOBSP the pseudo-first-order $\mathrm{R}^{2}$ value $(0.8621)$ is higher than 309 the pseudo-second-order $\mathrm{R}^{2}$ value. However, the pseudo-second-order value $(0.8307)$ is also high and 310 close to the pseudo-first-order value. Thus, it can be said that chemisorption is the rate-controlling 311 mechanism in the sorption of oil on both raw and acetylated AOBSP, with physisorption being partly 312 involved in the sorption process.

\section{$313 \quad$ 4.7.3 Isotherm studies}

314 The Langmuir isotherms for crude oil adsorption on raw and acetylated AOBSP are shown in Figures 31514 and 15, respectively, while the Freundlich isotherms are shown in Figures 16 and 17 for adsorption 316 on raw and acetylated AOBSP, respectively.

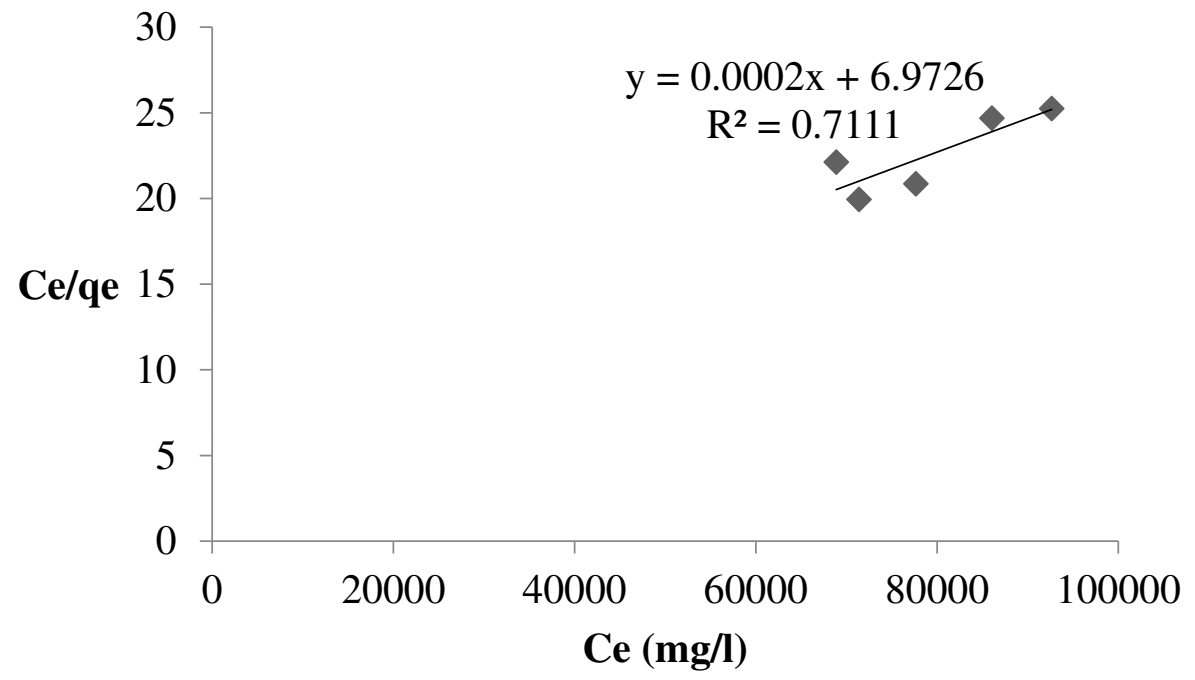




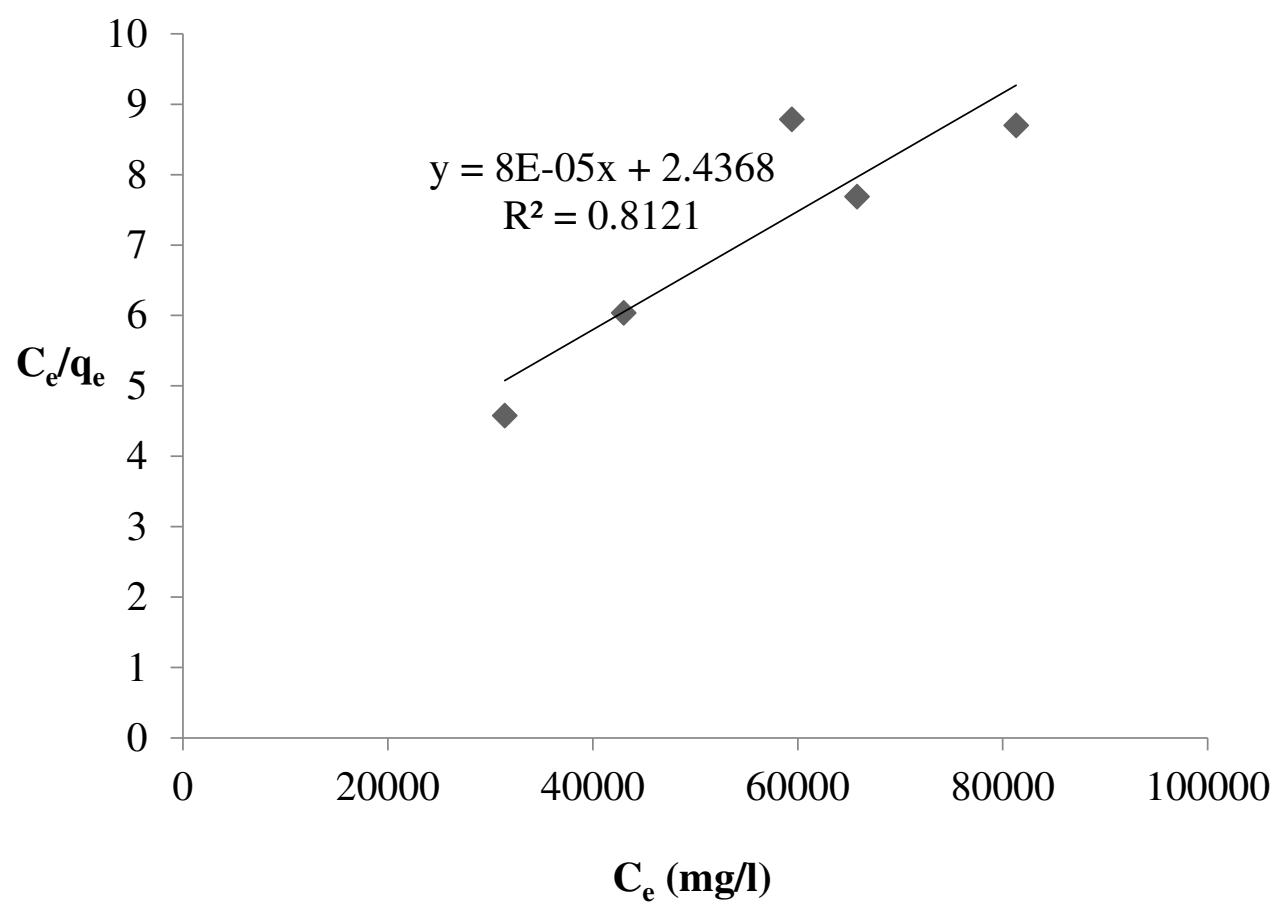

320

Figure 15: Langmuir isotherm for oil adsorption on acetylated AOBSP

321

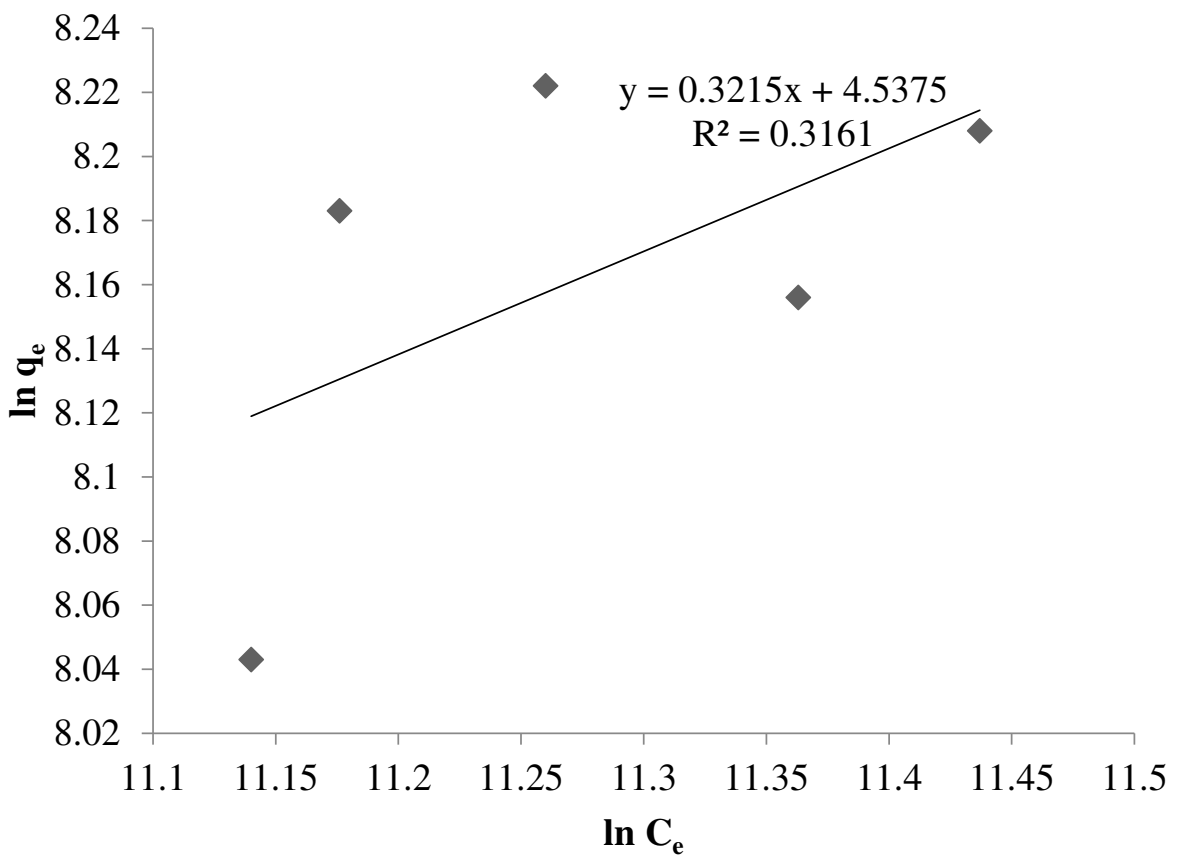

322

323 Figure 16: Freundlich isotherm for oil adsorption on raw AOBSP 


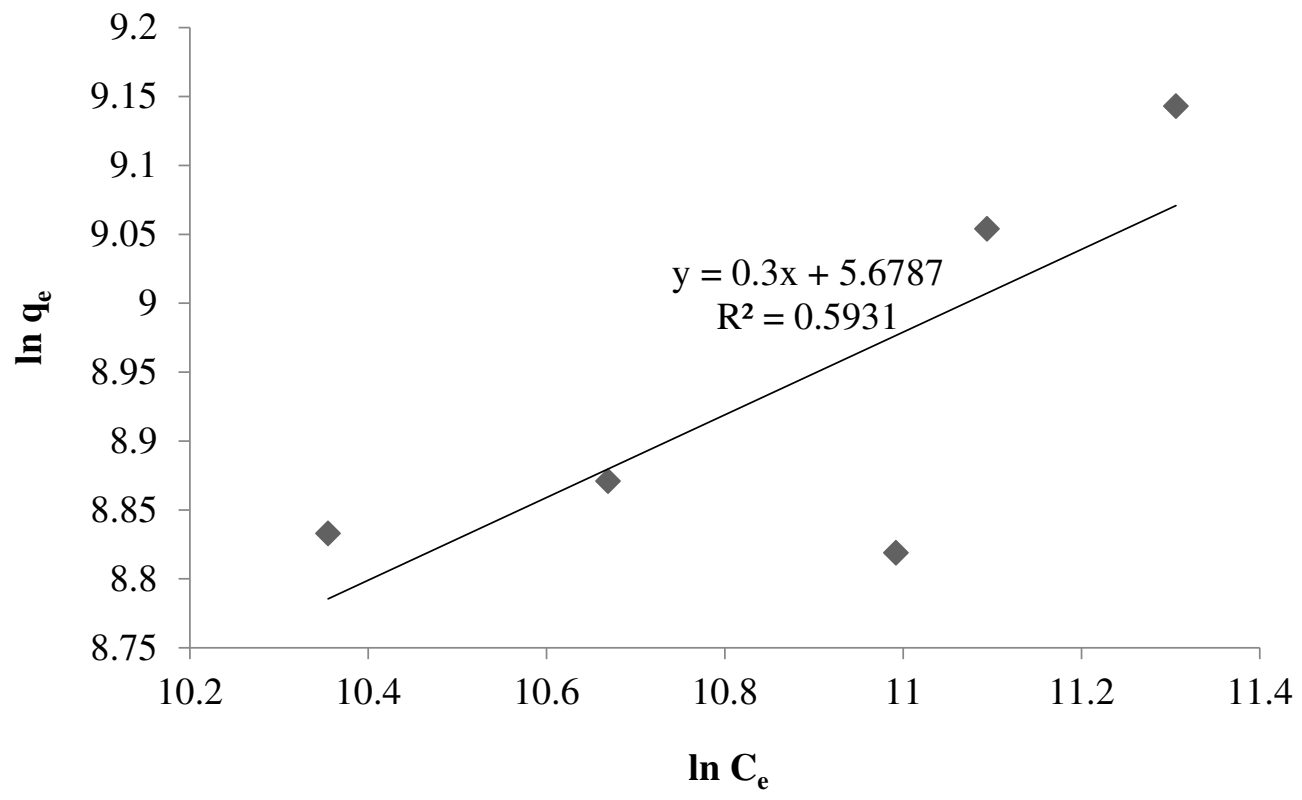

$326 \quad$ Figure 17: Freundlich isotherm for oil adsorption on acetylated AOBSP

327 The isotherm parameters for the crude oil adsorption on raw and acetylated AOBSP are shown in Table 3285.

329 Table 5: Isotherm parameters for oil adsorption on raw and acetylated AOBSP

\begin{tabular}{lcc}
\hline Parameter & RAOBSP & AAOBSP \\
\hline Langmuir isotherm & 0.7111 & 0.8121 \\
$\mathrm{R}^{2}$ & $2.87 \times 10^{-5}$ & $3.28 \times 10^{-4}$ \\
$\mathrm{~K}_{\mathrm{L}}(\mathrm{L} / \mathrm{mg})$ & 0.26 & 0.23 \\
$\mathrm{R}_{\mathrm{L}}$ & 5000 & 12500 \\
$\mathrm{q}_{\mathrm{m}}(\mathrm{mg} / \mathrm{g})$ & & \\
Freundlich $_{\text {isotherm }}$ & & \\
$\mathrm{R}^{2}$ & 0.3161 & 0.5931 \\
$\mathrm{~K}_{\mathrm{F}}$ & 93.457 & 292.57 \\
$\mathrm{n}$ & 3.11 & 3.33 \\
\hline
\end{tabular}


330 For both RAOBSP and AAOBSP the $\mathrm{R}^{2}$ values for Langmuir isotherm are higher than for Freundlich

331 isotherm. This means that the adsorption of crude oil on both RAOBSP and AAOBSP are better

332 described by Langmuir isotherm than Freundlich isotherm. This shows that oil adsorption on both

333 RAOBSP and AAOBSP took place by monolayer coverage of the sorbents by the crude oil with no

334 interaction between the adsorbed oil on adjacent sites (Mwangi et al. 2012). The $K_{L}$ value for adsorption

335 on AAOBSP $\left(3.28 \times 10^{-4} \mathrm{~L} / \mathrm{mg}\right)$ is higher than the value for adsorption on RAOBSP $\left(2.87 \times 10^{-5} \mathrm{~L} / \mathrm{mg}\right)$.

336 This shows that there was greater affinity between the crude oil and AAOBSP than between the crude 337 oil and RAOBSP. The RL values were 0.26 and 0.23 for RAOBSP and AAOBSP, respectively. These 338 values are between 0 and 1, thereby indicating the favourability of the adsorption of crude oil on both 339 sorbents (Siswoyo et al. 2014). The monolayer sorption capacity was found to be $5000 \mathrm{mg} / \mathrm{g}$ for 340 RAOBSP and $12500 \mathrm{mg} / \mathrm{g}$ for AAOBSP, which shows the high improvement of the sorption capacity 341 of AOBSP by acetylation. The sorption capacity of acetylated AOBSP is higher than some other 342 reported acetylated lignocellulosic wastes, such as acetylated groundnut husk with sorption capacity of 343 9940mg/g (Chiaha et al. 2017) and acetylated oil palm empty fruit bunch fibre with sorption capacity 344 of $10,000 \mathrm{mg} / \mathrm{g}$ (Asadpour et al. 2016)

\section{Thermodynamic studies}

346 The results of thermodynamic analysis of crude oil adsorption on the raw and acetylated AOBSP are 347 shown in Table 6. 


\begin{tabular}{lcc}
\hline Parameter & RAOBSP & AAOBSP \\
\hline$\Delta \mathrm{G}^{\mathrm{o}}(\mathrm{kJ} / \mathrm{mol})$ & & \\
$303 \mathrm{~K}$ & -10.120 & -12.031 \\
$308 \mathrm{~K}$ & -10.093 & -12.008 \\
$313 \mathrm{~K}$ & -9.920 & -11.996 \\
$318 \mathrm{~K}$ & -9.148 & -11.426 \\
$323 \mathrm{~K}$ & -8.650 & -10.365 \\
$\Delta \mathrm{H}^{\mathrm{o}}(\mathrm{kJ} / \mathrm{mol})$ & -33.906 & -36.067 \\
$\Delta \mathrm{S}^{\circ}(\mathrm{kJ} / \mathrm{mol})$ & -0.0777 & -0.0783 \\
\hline
\end{tabular}

For adsorption on both RAOBSP and AAOBSP, $\Delta \mathrm{G}^{\mathrm{o}}$ was found to have negative values at all the 355 considered adsorption temperatures, showing that adsorption on both RAOBSP and AAOBSP were 356 spontaneous and feasible and so did not require any external energy source (Adeogun et al. 2016). 357 Higher negative $\Delta \mathrm{G}^{\mathrm{o}}$ value shows a more energetically favorable adsorption (Kumar 2011). AAOBSP 358 was found to have higher negative $\Delta G^{0}$ values than RAOBSP at all the considered adsorption 359 temperatures showing that adsorption of crude oil on AAOBSP was more energetically favorable than 360 adsorption on RAOBSP. Also, lower negative $\Delta \mathrm{G}^{\circ}$ values were obtained with increase in temperature, 361 showing that there was more efficient biosorption at lower temperature, which is supported by the 362 decrease in the value of sorption capacity of the sorbents with increase in temperature observed during 363 the study of effect of temperature on adsorption. The $\Delta \mathrm{H}^{\mathrm{o}}$ values were negative values, also confirming 364 that crude oil adsorption on both RAOBSP and AAOBSP were exothermic processes. The $\Delta \mathrm{S}^{\circ}$ values 365 were found to be $-0.0777 \mathrm{~kJ} / \mathrm{mol}$ and $-0.0783 \mathrm{~kJ} / \mathrm{mol}$ for adsorption on RAOBSP and AAOBSP, 
respectively. The negative value of $\Delta \mathrm{S}^{\circ}$ shows that there was a reduction in randomness at the solid-

367 mixture interface during adsorption (Salisu et al. 2019). This is as a result of the adsorption of the oil 368 molecules to the sorbents' surfaces thereby leading to orderliness (Zhu et al. 2009). Also, according to 369 Nwosu et al. (2012), negative $\Delta \mathrm{S}^{\mathrm{o}}$ values show that the adsorption process did not result in any 370 significant change in the internal structure of the adsorbent. Thus, crude oil adsorption on both raw and 371 acetylated AOBSP was feasible, spontaneous, exothermic, and did not cause any significant change in 372 the internal structure of the adsorbent.

\section{CONCLUSION}

374 In this study, AOBSP, which is an agricultural waste, was found to be a suitable sorbent for crude oil 375 removal from aqueous solution. The sorption capacity increased substantially after acetylation. Crude 376 oil adsorption on both raw and acetylated AOBSP were spontaneous, exothermic, and did not cause 377 any significant change in the internal structure of the adsorbents. Adsorption on the raw pod was best 378 described by the pseudo first order kinetic model, while adsorption on the acetylated pod fitted best to 379 the pseudo second order model. Intra-particle diffusion also took part in controlling the rate of oil 380 sorption on both RAOBSP and AAOBSP. Adsorption on both raw and acetylated AOBSP took place 381 by monolayer coverage of the crude oil on the surface of the sorbents with the sorption capacity of the 382 raw and acetylated sorbents being $2500 \mathrm{mg} / \mathrm{g}$ and $12500 \mathrm{mg} / \mathrm{g}$, respectively. Acetylated AOBSP is a 383 very promising alternative sorbent for crude oil spill mop because of its high sorption capacity and the 384 fact that AOBSP is readily available and a biodegradable waste.

\section{Abbreviations}

386 AOBSP: African oil bean seed pod; RAOBSP: raw African oil bean seed pod; AOBSP: acetylated 387 African oil bean seed pod; RAOBSP-S: raw African oil bean seed pod after crude oil sorption; 388 AAOBSP-S: acetylated African oil bean seed pod after crude oil sorption; API: American Petroleum 
Institute; ATR: attenuated total reflection; ASTM: American Society for Testing and Materials; SEM:

Scanning electron microscopy; BET: Brunauer, Emmett and Teller; BJH: Barrett, Joyner, and Halenda;

DH: Dollimore and Heal; DR: Dubinin-Radushkevich; DFT: Density functional theory; HK: Horvath and Kawazoe; SF: Saito and Foley; DA: Dubinin-Astakhov; FTIR: Fourier-Transform Infrared; $\mathrm{W}_{0}$ : weight of adsorbent before oil adsorption; $\mathrm{W}_{1}$ : weight of adsorbent after oil adsorption; $\mathrm{C}_{\mathrm{o}}$ : initial crude oil concentration (mg/L); $\mathrm{C}_{\mathrm{e}}$ : equilibrium crude oil concentration (mg/L); m: mass of adsorbent (g); V: volume of solution (L); qe: amount of adsorbate adsorbed at equilibrium (mg/g); qt: amount of adsorbate adsorbed (mg/g); t: time (min); $\mathrm{k}_{1}$ : pseudo first order reaction rate constant $\left(\mathrm{min}^{-1}\right)$; $\mathrm{k}_{2}$ : pseudo-second order reaction rate constant (g/mg.min); Kid: rate constant of intraparticle diffusion $\left(\mathrm{mg} /\left(\mathrm{g} \cdot \mathrm{min}^{0.5}\right)\right)$;

$\mathrm{K}_{\mathrm{L}}$ : Langmuir constant (L/mg); $\mathrm{R}_{\mathrm{L}}$ : Langmuir separation factor; $\mathrm{C}_{\mathrm{o}}$ : initial adsorbate concentration(mg/L); $\mathrm{K}_{\mathrm{F}}$ : Freundlich constant $\left[(\mathrm{mg} / \mathrm{g}) /(\mathrm{mg} / \mathrm{L})^{1 / \mathrm{n}}\right] ; \mathrm{n}$ : measure of adsorption intensity; adsorption $\left(\mathrm{cm}^{3} / \mathrm{g}\right) ; \Delta \mathrm{G}^{\mathrm{o}}$ : standard Gibbs free energy change $(\mathrm{kJ} / \mathrm{mol}) ; \Delta \mathrm{H}^{\mathrm{o}}$ : change in enthalpy

$402(\mathrm{~kJ} / \mathrm{mol}) ; \Delta \mathrm{S}^{\mathrm{o}}$ : change in entropy $(\mathrm{kJ} / \mathrm{mol} . \mathrm{K})$.

\section{DECLARATIONS}

\section{Ethics approval and consent to participate}

405 Not applicable

406 Consent for publication

407 Not applicable

\section{Availability of data and materials}

409 All data generated or analysed during this study are included in this published article (and its 410 supplementary information files). 


\section{Competing interests}

413 The authors declare that they have no competing interests.

\section{$414 \quad$ Funding}

415 The work was funded by the authors.

\section{Authors' contributions}

417 AIO who is a doctoral candidate wrote the manuscript. VIA is the supervisor and provided comments 418 and revisions to the manuscript. All authors read and approved the final manuscript.

\section{Acknowledgement}

420 Not applicable

\section{REFERENCES}

423 Adeogun AI, Idowu MA, Akiode KO, Ahmed SA (2016) Bioremediation of Cu(II) contaminated water 424 by Saccharum officinarum: effect of oxalic acid modification on equilibrium, kinetic 425 and thermodynamic parameters. Bioresour Bioprocess. 3:7. doi:10.1186/s40643-016-0085-9

426 Akinhanmi TF, Ofudje EA, Adeogun AI, Aina P, Joseph IM (2020) Orange peel as low-cost adsorbent 427 in the elimination of $\mathrm{Cd}(\mathrm{II})$ ion: kinetics, isotherm, thermodynamic and optimization evaluations. 428 Bioresour Bioprocess. 7:34. doi:10.1186/s40643-020-00320-y

429 Al-Dahhan WH, Mahmood SMA (2019) Classification of crude oils and its fractions on the basis of 430 paraffinic, naphthenic and aromatics. Al-Nah J Sci 22(3):35-42. doi:10.22401/ANJS.22.3.05

431 Angelova D, Uzunov I, Uzunova, Gigova, Minchev, L (2011) Kinetics of oil and oil products 432 adsorption by carbonized rice husks. Chem Eng J 172(1):306-311. doi:10.1016/j.cej.2011.05.114 
433 Aningo JN, Chime TO, Nevo CO (2017) Adsorption of cadmium (II) ion from aqueous solution using 434 activated carbon from produced from oil been seed shell. J Multidis Eng Sci Tech 4(8):7993-8000.

435 Anuzyte E, Vaisis V (2018) Natural oil sorbents modification methods for hydrophobicity 436 improvement. Ene Proc 147:295-300. doi:10.1016/j.egypro.2018.07.095

437 Arinze-Nwosu UL, Ajiwe VIE, Okoye PAC, Nwadiogbu JO (2019) Kinetics and equilibrium of crude 438 oil sorption from aqueous solution using Borassus aeothopum coir. Chem Mat Res 11(2):12-19. 439 doi:10.7176/CMR

440 Asadpour R, Sapari NB, Isa MH, Kakooei S (2016) Acetylation of oil palm empty fruit bunch fiber as 441 an adsorbent for removal of crude oil. Environ Sci Pollut Res 23(12):11740-11750. 442 doi:10.1007/s11356-016-6349-2

443 Asadpour R, Sapari NB, Isa MH, Orji KU (2014). Enhancing the hydrophobicity of mangrove bark by 444 esterification for oil adsorption. Wat Sci Tech 70(7):1220-1228. doi:10.2166/wst.2014.355

445 Asadpour R, Sapari NB, Isa MH, Kakooei S, Orji KU (2015) Acetylation of corn silk and its application 446 for oil sorption. Fib Poly 16(9):1830-1835. doi:10.1007/s12221-015-4745-8

447 Awadh SM, Al-Mimar H (2015) Statistical analysis of the relations between API, specific gravity and 448 sulfur content in the universal crude oil. Int J Sci Res 4(5), 1279-1284.

449 Babarinde NAA, Babalola JOB (2010) The biosorption of Pb (II) from solution by elephant grass 450 (Pennisetum purpureum): kinetic, equilibrium, and thermodynamic studies. The Pacific Journal of 451 Science and Technology, 11(1), 622-630.

452 Barros FCDF, Vasconcellos LCG, Carvalho TV, Nascimento RFD (2014) Removal of petroleum spill 453 in water by chitin and chitosan. Orbital: Elec J Chem 6(1):70-74. doi: 10.17807/orbital.v6i1.509 
454 Bodîrlău R, Teacă CA (2009) Fourier transform infrared spectroscopy and thermal analysis of 455 lignocellulose fillers treated with organic anhydrides. Rom Journ Phys 54(1-2):93-104.

456 Chiaha PN, Nwabueze HO, Ezekannagha CB, Okenwa CJ (2017) Kinetic studies on oil sorption using 457 acetylated sugarcane bagasse and groundnut husk. Int J Multidis Sci Eng, 8(6):16-21.

458 Dagde KK (2018). Biosorption of crude oil spill using groundnut husks and plantain peels as 459 adsorbents. Adv Chem Eng Sci 8:161-175. doi:10.4236/aces.2018.83011

460 El-Din GA, Amer AA, Malsh G, Hussein M (2018) Study on the use of banana peels for oil spill 461 removal. Alex Eng J 57:2061-2068. doi:10.1016/j.aej.2017.05.020

462 Erhan D, Mehmet K, Elif S, Tuncay O (2004) Adsorption kinetics for the removal of chromium (VI) 463 from aqueous solutions on the activated carbons prepared from agricultural wastes. Wat SA, 30(4):533464541.

465 Gupta VK, Shrivastava AK, Jain N (2001) Biosorption of chromium (VI) from aqueous solutions by 466 green algae spirogyra species. Wat Res 35:4079-4090. doi:10.1016/s0043-1354(01)00138-5

467 Ho YS, McKay G (2000) The kinetics of sorption of divalent metal ions onto sphagnum moss peat. 468 Wat Res 34(3):735-742.

469 Idris S, Iyaka YA, Dauda BEN, Ndamitso MM, Umar MT (2012) Kinetic study of utilizing groundnut 470 shell as an adsorbent in removing chromium and nickel from dye effluent. Amer Chem Sci J 2(1):1247124.

472 Ikirigo J, Sogbara F (2017) Perspective view on sorption thermodynamics: basic dye uptake on 473 southern Nigerian clay. Euro Sci J 13(18):355-372. doi:10.19044/ESJ.2017.V13N18P355 
474 Karthikeyan G, Analagan K, Andal NM (2004) Adsorption dynamics and equilibrium studies of Zn

475 (II) onto chitosan. J Chem Sci 116(2):119-127.

476 Kudaybergenov, K.K., Ongarbayev, E.K. and Mansurov, Z.A. (2013) Petroleum sorption by thermally

477 treated rice husks derived from agricultural byproducts. Eura Chemico-Technol J 15:57-66. 478 doi:10.18321/ectj141

479 Kumar, U. (2011) Thermodynamics of the Adsorption of Cd (II) from Aqueous Solution on NCRH. 480 International J Environ Sci Dev 2(5):334-336. doi:10.7763/IJESD.2011.V2.147

481 Li Y, Hagos FM, Chen R, Qian H, Mo C, Di J, Gai X, Yang R, Pan G, Shan S (2021) Rice husk 482 hydrochars from metal chloride-assisted hydrothermal carbonization as biosorbents of organics 483 from aqueous solution. Bioresour Bioprocess 8:99. doi:10.1186/s40643-021-00451-w.

484 Li K, Zheng Z, Huang X, Zhao G, Feng J, Zhang J (2009) Equilibrium, kinetic and thermodynamic 485 studies on the adsorption of 2-nitroaniline onto activated carbon prepared from cotton stalk fiber. J Haz 486 Mat 166(1):213-220. doi:10.1016/j.jhazmat.2008.11.007

487 Madu AJC, Ugwu RE (2017). Physical and chemical properties of crude oils and their geologic 488 significances. Int J Sci Res 6(6):1514-1521.

489 Mahmoud MA (2020) Oil spill cleanup by waste flax fiber: modification effect, sorption isotherm, 490 kinetics and thermodynamics. Arab J Chem, 13:5553-5563. doi:10.1016/j.arabjc.2020.02.014

491 Mwangi IW, Ngila JC and Okonkwo JO (2012) A comparative study of modified and unmodified 492 maize tassels for the removal of selected trace metals in contaminated water. Tox Environ Chem 94:20493 39. doi:10.1080/02772248.2011.638636 
Najaa-Syuhada MT, Rozidaini MG, Norhisyam I (2017). Response surface methodology optimization 495 of oil removal using banana peel as biosorbent. Malay J Anal Sci, 21(5), 1101 - 1110. 496 doi:10.17576/mjas-2017-2105-12

497 Nwabueze HO, Igbokwe PK, Amalu EU, Okoro SE (2015). A study on the equilibrium and kinetics of 498 oil spill cleanup using acetylated corncobs. Int J Environ Sci, 5(6):1106-1114.

499 Nwadiogbu JO, Ajiwe VIE, Okoye PAC (2016). Removal of crude oil from aqueous medium by 500 sorption on hydrophobic corncobs: Equilibrium and kinetic studies. J Taibah Univ Sci, 10, 56 - 63. 501 doi:10.1016/j.jtusci.2015.03.014

502 Nwosu FO, Olu-Owolabi BI, Adebowale KO (2012). Kinetics and thermodynamic adsorption of Pb 503 (II) and Cd (II) ions from used oil onto Thevetia neriifolia nutshell active carbon. Curr Res Chem 504 4(2):26-40. doi:10.3923/crc.2012.26.40

505 Nwosu, UC, Essien EB, Ohiri RC (2017). Phytochemical, mineral composition and anti506 hyperlipidemic effects of processed Pentaclethra macrophylla seeds on high fat diet and streptozocin507 induced diabetic wistar rats. Int J Agri Earth Sci 3(6):31-41. doi:10.9734/IJBCRR/2017/35235

508 Ofomaja AE, Ho Y (2007). Effect of pH on cadmium biosorption by coconut copra meal. J Haz Mat. 509 139(2), 356 - 362. doi:10.1016/j.jhazmat.2006.06.039

510 Okwunodulu FU, Odoemelam SA, Okon EN (2015). Biosorption of $\mathrm{Cd}^{2+}, \mathrm{Ni}^{2+}$ and $\mathrm{Pb}^{2+}$ by the shell 511 of Pentaclethra macrophylla: equilibrium isotherm studies. J. Sci. Technol. Environ. Inform 2(1):26$512 \quad 35$. doi:10.18801/jstei.020115.13

513 Oloro J (2018). Effect of pH and API gravity on the water-in-oil emulsion stability. J Appl Sci Environ 514 Manage, 22(6):925-928. doi:10.4314/jasem.v22i6.14 
515 Omer AM, Khalifa RE, Tamer TM, Ali AA, Ammar YA, Eldina MSM (2020) Kinetic and

516 thermodynamic studies for the sorptive removal of crude oil spills using a low-cost chitosan-poly (butyl

517 acrylate) grafted copolymer. Desal Water Treat 192:213-225. doi: 10.5004/dwt.2020.25704

518 Onwuka JC, Agbaji E, Ajibola VO, Okibe F (2016) Kinetic studies of surface modification of 519 lignocellulosic Delonix regia pods as sorbent for crude oil spill in water. J Appl Res Technol 14:415520 424. doi:10.1016/j.jart.2016.09.004

521 Onwuka JC, Agbaji E, Ajibola VO, Okibe F (2019) Thermodynamic pathway of lignocellulosic 522 acetylation process. BMC Chem, 13:79-90. doi:10.1186/s13065-019-0593-8

523 Onwuka JC, Agbaji E, Ajibola VO, Okibe F (2018) Treatment of crude oil-contaminated water 524 with chemically modified natural fiber. Appl Water Sci 8(86):1-10. doi:10.1007/s13201-018-0727-5

525 Santos CM, Dweck J, Viotto RS, Rosa AH, de Morais LC (2015) Application of orange peel waste in 526 the production of biofuels and biosorbents. Biores Tech 196:469-479. 527 doi:10.1016/j.biortech.2015.07.114

528 Shah AJ, Soni B, Karmee SK (2021) Locally available agroresidues as potential sorbents: modelling, 529 column studies and scale-up. Bioresour Bioprocess. 8:34. doi:10.1186/s40643-021-00387-1

530 Shittu TD, Aransiola EF, Alabi-Babalola OD (2020). Adsorption performance of modified sponge 531 gourd for crude oil removal. J Environ Protect, 11:65-81. doi:10.4236/jep.2020.112006

532 Shweta S, Jha H (2016) Synthesis and characterization of crystalline carboxymethylated lignin - TEOS 533 nanocomposites for metal adsorption and antibacterial activity. Bioresour Bioprocess 3:31. doi: $534 \quad 10.1186 / \mathrm{s} 40643-016-0107-7$ 
535 Simonivić BR, Aranđelović D, Jovanović M, Kovačević B, Pezo L, Jovanović A (2009). Removal of 536 mineral oil and wastewater pollutants using hard coal. Chem Ind Chem Eng Q 15(2):57-62. 537 doi:10.2298/CICEQ0902057S

538 Teli MD, Valia SP (2016) Effect of substrate geometry on oil sorption capacity of raw and chemically 539 modified jute fibre. IRA-Int J Technol Eng 3(3):138-147. doi:10.21013/jte.v3.n3.p4

540 Thompson NE, Emmanuel GC, George NI, Adamu IK (2015) Modelling of the kinetic and equilibrium 541 sorption behaviour of crude oil on HDTMAB modified Nigerian nanoclays. Int J Sci Technol 4(2):106542114

543 Wali E, Nwankwoala HO, Ocheje JF, Onyishi CJ (2019) Oil spill incidents and wetlands loss in Niger 544 delta: implication for sustainable development goals. Int J Environ Poll Res 7(1):1-20.

545 Xu Y, Yang H, Zang D, Zhou Y, Liu F, Huang X, Chang J, Wang C, Ho S (2018) Preparation of a new 546 superhydrophobic/ superoleophilic corn straw fiber used as an oil absorbent for selective absorption of 547 oil from water. Bioresour Bioprocess 5:8. doi:10.1186/s40643-018-0194-8

548 Yasin G, Bhanger MI, Ansari TM, Naqvi SMSR, Ashraf M, Ahmad K, Talpur FN (2013). Quality and 549 chemistry of crude oils. J Pet Technol Alt Fuels 4(3):53-63.

550 Zhu C, Wang L, Chen W (2009) Removal of Cu(II) from aqueous solution by agricultural by-product: 551 peanut hull. J Haz Mat 168:739-746. 


\begin{tabular}{llc}
\hline Measurement & Raw & Acetylated \\
& AOBSP & AOBSP \\
\hline Surface area $\left(\mathbf{m}^{2} / \mathbf{g}\right)$ & & \\
SinglePoint BET & 137.7 & 192.0 \\
MultiPoint BET & 226.4 & 310.0 \\
Langmuir surface area & 1358 & 1620 \\
BJH method cumulative adsorption surface area & 255.1 & 355.1 \\
DH method cumulative adsorption surface area & 271.3 & 378.3 \\
t-method external surface area & 226.4 & 310.0 \\
DR method micropore area & 242.4 & 335.8 \\
DFT cumulative surface area & 53.93 & 74.76 \\
Pore volume (cc/g) & & \\
BJH method cumulative adsorption pore volume & 0.1254 & 0.1741 \\
DH method cumulative adsorption pore volume & 0.1283 & 0.1783 \\
DR method micropore volume & 0.0861 & 0.1193 \\
HK method micropore volume & 0.0359 & 0.0505 \\
SF method micropore volume & 0.0074 & 0.0108 \\
DFT method cumulative pore volume & 0.0652 & 0.0895 \\
Pore size (nm) & & 2.1840 \\
BJH method adsorption pore diameter & 2.123 \\
DH method adsorption pore diameter & & \\
DR method micropore width & & \\
DA method pore diameter & & \\
\hline
\end{tabular}


HK method pore diameter

SF method pore diameter

DFT pore diameter
1.847
$1.847 \quad 557$

3.488

2.647 


\section{Supplementary Files}

This is a list of supplementary files associated with this preprint. Click to download.

- ADDITIONALFILES.docx

- GRAPHICALABSTRACT.jpg 